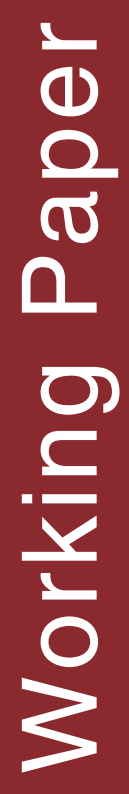

Riyandoko dan Endri Martini 



\section{Preferensi Petani terhadap Topik Penyuluhan dan Penyebaran Informasi Agroforestri di Indonesia}

Riyandoko dan Endri Martini 


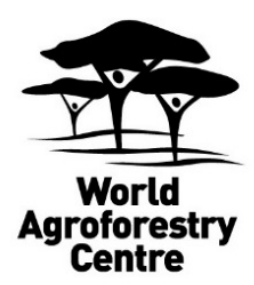

Correct citation:

Riyandoko and Martini E. 2017. Preferensi Petani terhadap Topik Penyuluhan dan Penyebaran Informasi Agroforestri di Indonesia. Working paper no. 252. Bogor, Indonesia: World Agroforestry Centre (ICRAF) Southeast Asia Regional Program. http://dx.doi.org/10.5716/WP16181.PDF

Titles in the Working Paper series aim to disseminate interim results on agroforestry research and practices, and stimulate feedback from the scientific community. Other publication series from the World Agroforestry Centre include: Technical Manuals, Occasional Papers and the Trees for Change Series.

Published by the World Agroforestry Centre (ICRAF)

Southeast Asia Regional Program

JL. CIFOR, Situ Gede, Sindang Barang, Bogor 16680

PO Box 161, Bogor 16001, Indonesia

Tel: +622518625415

Fax: +622518625416

Email: icraf-indonesia@cgiar.org

ICRAF Southeast Asia website: http://www.worldagroforestry.org/region/southeast-asia/

(C) World Agroforestry Centre 2017

Working Paper 252

\section{Photographs:}

The views expressed in this publication are those of the author(s) and not necessarily those of the World Agroforestry Centre.Articles appearing in this publication may be quoted or reproduced without charge, provided the source is acknowledged. All images remain the sole property of their source and may not be used for any purpose without written permission of the source. 


\section{Tentang Penulis}

Riyandoko adalah peneliti penyuluhan agroforestri di World Agroforestry Centre (ICRAF) yang sejak tahun 2015 bekerja pada isu pengembangan produksi dan strategi pasar kayu dan hasil hutan bukan kayu untuk peningkatan penghidupan petani di Indonesia. Beliau pernah bekerja dalam bidang pendidikan, penyuluhan dan pemberdayaan masyarakat di berbagai daerah di Indonesia seperti Sumatera, Jawa, Kalimantan, Sulawesi dan Nusa Tenggara. Riyandoko menyandang gelar sarjana peternakan dari Universitas Wangsa Manggala Yogyakarta.

Endri Martini saat ini bekerja di World Agroforestry Centre (ICRAF) sebagai peneliti penyuluhan agroforestri sejak tahun 2011. Beliau bergabung dengan ICRAF sejak tahun 2001 dan bekerja dalam berbagai topik agroforestri seperti konservasi keanekaragaman hayati dan pengelolaan sumber daya alam berbasis masyarakat. Gelar S1 diperolehnya dari Jurusan Silvikultur di Fakultas Kehutanan, Institut Pertanian Bogor. Gelar S2 bidang Sumber Daya Alam dan Pengelolaan Lingkungan diperolehnya dari University of Hawaii at Manoa, Hawaii, USA. 


\section{Abstrak}

Agroforestri telah diterapkan oleh masyarakat di Indonesia sejak lama menggunakan cara-cara tradisional. Berbagai penelitian mengenai agroforestri telah banyak dihasilkan, baik oleh lembagalembaga penelitian dalam dan luar negeri. The World Agroforestry Centre (ICRAF), adalah salah satu lembaga penelitian internasional di bidang agroforestri. Salah satu proyek penelitian yang dilakukan atas dana dari Australian Centre for International Agricultural Research (ACIAR) - FST 2012-039 adalah proyek penelitian pengembangan produksi, strategi pemasaran kayu dan hasil hutan bukan kayu (KANOPPI). Hasil-hasil penelitian tersebut kemudian disebarkan kepada petani melalui pelatihan dengan harapan dapat meningkatkan kesejahteraan bagi petani agroforestri di berbagai tempat di Indonesia. Tingkat adopsi petani terhadap informasi atau pengetahuan yang diberikan melalui pelatihan akan tergantung pada ketertarikan petani terhadap topik yang diberikan, jika petani tertarik pada topik tersebut maka petani akan menyebarkannya ke petani lainnya. Untuk itu, pada Maret-Juni 2016, studi ini dilakukan untuk mengetahui preferensi petani terhadap topik pelatihan atau penyuluhan dan proses penyebaran informasi dilakukan di Kabupaten Sumbawa, Nusa Tenggara Barat; Kabupaten Gunungkidul, Daerah Istimewa Yogyakarta dan Kabupaten Timor Tengah Selatan, Nusa Tenggara Timur. Wawancara semi terstruktur dilakukan untuk mengumpulkan informasi tentang kesukaan petani terhadap topik pelatihan, penerimaan petani terhadap teknologi baru agroforestri, dan materi pelatihan atau penyuluhan yang diharapkan oleh petani. Evaluasi oleh peserta pelatihan terhadap kegiatan pelatihan dan penyuluhan juga dilakukan untuk mendapatkan masukan sebagai bahan perbaikan pelatihan atau penyuluhan agroforestri di masa yang akan datang. Wawancara dilakukan terhadap 110 petani sebagai responden, yang terdiri dari 56 responden yang merupakan peserta pelatihan dan penyuluhan yang dilakukan oleh tim proyek Kanoppi, dan 54 responden non peserta pelatihan yang tidak mengikuti pelatihan yang diberikan oleh tim Kanoppi, $29 \%$ dari total responden adalah perempuan. Responden dipilih secara acak dari peserta pelatihan atau penyuluhan agroforestri dan kehutanan yang dilakukan di masing-masing kabupaten setahun sebelumnya dan petani bukan peserta pelatihan. Data dianalisa secara kualitatif dan kuantitatif. Hasil penelitian menunjukkan bahwa petani di ketiga kabupaten menyukai penyuluhan agroforestri yang lebih terfokus pada topik silvikultur, pengelolaan kebun agroforestri dan pemasaran hasil agroforestri. Kesukaan petani terhadap topik penyuluhan tersebut berbeda-beda tergantung pada lokasi dan gender. Dalam hal penyebaran informasi, penyuluh masih memiliki peran penting bagi petani sebagai sumber informasi. Perempuan yang mempunyai akses lebih rendah terhadap penyuluh, mengandalkan keluarga, kelompok tani dan petani unggul sebagai sumber informasi. Di daerah yang lebih terpencil seperti Nusa Tenggara, memiliki sumber informasi lebih sedikit dibandingkan dengan daerah yang lebih maju seperti di Gunungkidul, DI Yogyakarta. Sumber informasi yang terpercaya, teknologi sederhana dan tepat sasaran mempengaruhi proses adopsi teknologi yang diperkenalkan pada petani. Sebagai perbaikan, pengemasan pelatihan atau penyuluhan agroforestri di ketiga kabupaten lebih 
difokuskan pada produksi, pemasaran hasil hutan kayu dan bukan kayu dengan memperhatikan latar belakang peserta, metode, materi, waktu dan durasi pelatihan atau penyuluhan.

Kata kunci: Gunungkidul, Sumbawa, Timor Tengah Selatan, Topik Penyuluhan, Sumber Informasi 


\section{Ucapan Terima Kasih}

Studi ini terlaksana atas pendanaan dari Australian Centre for International Agricultural Research (ACIAR) melalui proyek penelitian Pengembangan Produksi dan Strategi Pemasaran Kayu dan Hasil Hutan Bukan Kayu bagi Petani di Indonesia (FST/2012/039 [KANOPPI]).

Penulis ingin mengucapkan terima kasih kepada responden yang berasal dari: Sumbawa, Gunungkidul dan Timor Tengah Selatan yang telah menyediakan waktu untuk menerima peneliti dan memberikan informasi yang dibutuhkan dalam penelitian ini. Terima kasih juga diucapkan kepada mitra Kanoppi di lokasi penelitian: Bapak Junaidin (Desa Batudulang Sumbawa); Bapak Suwardi (Desa Pelat Batudulang Sumbawa); Balai Pelaksanaan Penyuluhan Kecamatan Unter Iwes, Sumbawa; Bapak Sumardamto Purnomo; Dinas Kehutanan dan Perkebunan Kabupaten Gunungkidul; Kelompok Kerja Hutan Rakyat Lestari Kabupaten Gunungkidul; Badan Penyuluhan dan Ketahanan Pangan Gunungkidul; Dinas Kehutanan Timor Tengah Selatan dan Badan Ketahanan Pangan dan Penyuluhan Timor Tengah Selatan atas dukungan dan fasilitasi dalam pengumpulan data di masing-masing lokasi. Terima kasih diucapkan kepada Ibu Subekti Rahayu yang telah membantu dalam penyuntingan lembar kerja ini sehingga lebih jelas dibaca. Terakhir kami sampaikan terimakasih kepada Bapak Aulia Perdana selaku pimpinan proyek KANOPPI yang telah memberikan dukungan, saran dan masukan dalam setiap proses studi dari awal sampai terpublikasinya lembar kerja ini. 


\section{Daftar isi}

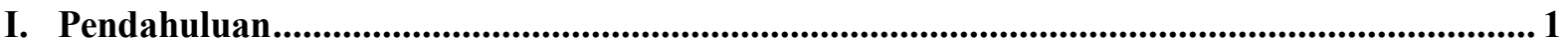

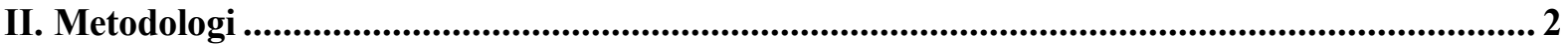

II.1 Waktu dan lokasi studi ...................................................................... 2

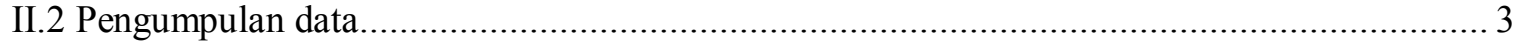

II.3 Analisa data ........................................................................................... 4

III. Hasil dan Pembahasan ........................................................................................................ 4

III.1 Pelatihan bagi penyuluh swadaya dan petani unggul .......................................... 4

III.2 Preferensi petani terhadap topik pelatihan agroforestri ......................................... 5

III.3 Proses Penyebaran Informasi Agroforestri ................................................ 7

III.4 Keterkaitan antara sumber informasi, materi informasi dengan proses adopsi ................. 17

III.5 Pengemasan pelatihan atau penyuluhan agroforestri yang sesuai kebutuhan petani ............ 18

IV. Kesimpulan dan Saran ............................................................................................. 22

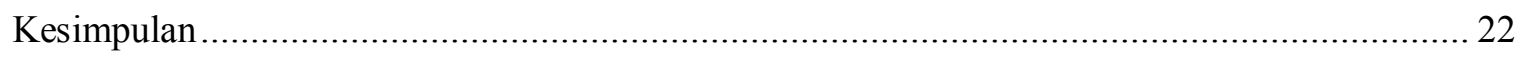

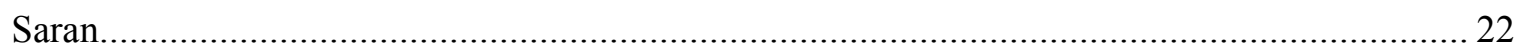

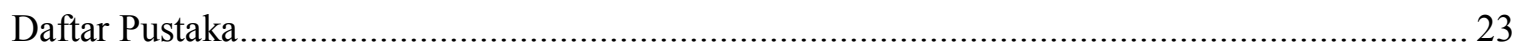




\section{Daftar Tabel}

Tabel 1. Karakteristik lokasi studi di Kabupaten Gunungkidul, Sumbawa dan Timor Tengah Selatan.

Tabel 2. Proporsi jumlah responden di masing-masing kabupaten

Tabel 3. Jumlah peserta pelatihan tentang kayu dan hasil hutan bukan kayu bagi penyuluh swadaya dan petani unggul di Gunungkidul, Sumbawa, dan Timor tengah Selatan.

Tabel 4. Preferensi petani terhadap topik pelatihan agroforestri.

Lampiran 1. Silabus Pelatihan bagi Penyuluh Swadaya dan Petani Unggul tentang Pengembangan Produksi dan Strategi Pemasaran Kayu dan Hasil Hutan Bukan Kayu.

\section{Daftar Gambar}

Gambar 1. Peta lokasi pelatihan bagi penyuluh swadaya dan petani unggul proyek KANOPPI tahun 2015.

Gambar 2. Diagram jaringan sumber-sumber informasi tentang agroforestri dan kehutanan di semua kabupaten lokasi studi berdasarkan perbedaan gender.

Gambar 3. Perbedaan prioritas sumber-sumber informasi agroforestri dan kehutanan antara

Kabupaten Gunungkidul, Sumbawa, dan Timor Tengah Selatan.

Gambar 4. Diagram jaringan sosial sumber informasi tentang agroforestri dan kehutanan bagi petani lelaki dan perempuan di Gunungkidul.

Gambar 5. Diagram jaringan sosial sumber informasi tentang agroforestri dan kehutanan bagi petani lelaki dan perempuan di Sumbawa.

Gambar 6. Diagram jaringan sosial sumber informasi tentang agroforestri dan kehutanan bagi petani lelaki dan perempuan di Timor Tengah Selatan.

Gambar 7. Diagram jaringan sosial sumber informasi petani pada topik kayu dan hasil hutan bukan kayu

Gambar 8. Diagram jaringan sosial sumber informasi petani pada topik pemasaran kayu dan hasil hutan bukan kayu

Gambar 9. Diagram jaringan sosial sumber informasi petani pada topik kebijakan terkait penatausahaan hasil hutan hak milik

Gambar 10. Diagram jaringan sosial sumber informasi petani pada topik silvikultur

Gambar 11. Diagram jaringan sosial sumber informasi petani pada topik pengelolaan kebun agroforestri

Gambar 12. Persepsi petani terhadap aspek-aspek yang mempengaruhi proses adopsi teknologi agroforestri.

Gambar 13. Kriteria peserta pelatihan dan penyuluhan agroforestri berdasarkan masukan responden.

Gambar 14. Metode pelatihan atau penyuluhan agroforestri yang dipilih responden.

Gambar 15. Durasi hari untuk pelatihan atau penyuluhan yang disarankan baik oleh lelaki maupun perempuan 


\section{Daftar Singkatan/ Istilah}

ACIAR: Australian Centre for International Agricultural Research

BPDAS: $\quad$ Balai Pengelolaan Daerah Aliran Sungai

BPTHHBK: Balai Penelitian dan Teknologi Hasil Hutan Bukan Kayu

BPTP: $\quad$ Balai Pengkajian Teknologi Pertanian

BP4K: Badan Pelaksana Penyuluhan Pertanian, Perikanan dan Kehutanan

HHBK: $\quad$ Hasil Hutan Bukan Kayu

ICRAF: The World Agroforestry Centre

KPH: $\quad$ Kesatuan Pengelolaan Hutan

KPHP: $\quad$ Kesatuan Pengelolaan Hutan Produksi

LSM: $\quad$ Lembaga Swadaya Masyarakat 



\section{Pendahuluan}

Agroforestri merupakan praktik pengelolaan lahan yang sudah lama diterapkan oleh masyarakat di Indonesia (Hairiah et al 2003). Sistem pengelolaan lahan yang merupakan perpaduan antara ilmu kehutanan dan pertanian ini dikembangkan untuk menciptakan keselarasan antara intensifikasi pertanian dan pelestarian hutan (de Foresta et al 2000). Agroforestri secara sederhana merupakan pendekatan pengelolaan lahan yang melibatkan integrasi antara pohon dengan tanaman semusim dan atau hewan ternak dalam waktu dan ruang yang sama. Dalam praktiknya, agroforestri dikelompokkan menjadi dua yaitu: agroforestri sederhana dan agroforestri kompleks (Nair 1993). Agroforestri sederhana berupa sistem tumpang sari antara satu jenis pohon dengan satu jenis atau lebih tanaman semusim, sedangkan agroforestri komplek adalah jika dalam satu lahan terdapat lebih dari satu jenis pohon dengan tanaman semusim dan atau hewan ternak. Jenis pohon yang dapat diintegrasikan dalam sistem agroforestri dapat berupa pohon penghasil kayu dan pohon penghasil bukan kayu seperti buahbuahan dan getah.

Meskipun berbagai jenis pohon telah lama diintegrasikan dalam sistem agroforestri oleh petani, tetapi belum mampu memberikan peningkatan hasil secara optimal. Hal tersebut terjadi karena keterbatasan pengetahuan petani mengenai praktik budidaya kayu (silvikultur), pengukuran kubikasi kayu, praktik pengelolaan agroforestri terbaik, pemasaran hasil kayu dan hasil hutan bukan kayu, serta kebijakan yang terkait penata-usahaan hasil hutan hak milik (Putro et al 2015). Rendahnya layanan penyuluhan karena keterbatasan jumlah penyuluh kehutanan pemerintah dan program penyuluhan kehutanan serta agroforestri menjadi penyebab rendahnya pengetahuan petani. Berdasarkan studi baseline yang dilakukan oleh Tim Kanoppi, akses petani terhadap kegiatan penyuluhan kehutanan dan agroforestri di Kabupaten Gunungkidul hanya 41,18\%, di Sumbawa 30,54\%; dan di Timor Tengah Selatan $14,73 \%$ (Riyandoko et al 2016a).

Sebagai bentuk dukungan untuk meningkatkan kapasitas penyuluh di Kabupaten Gunungkidul, Sumbawa dan Timor Tengah Selatan, yang merupakan lokasi penelitian Kanoppi, the World Agroforestry Centre dan mitranya pada tahun 2015 memberikan pelatihan bagi penyuluh swadaya dan petani unggul. Materi yang diberikan dalam pelatihan selama empat hari adalah: (i) pengantar kayu dan hasil hutan bukan kayu, (ii) kebijakan yang terkait penata-usahaan hasil hutan hak milik, (iii) pemasaran kayu dan hasil hutan bukan kayu, (iv) pemeliharaan tanaman kayu (silvikultur), (v) pengelolan kebun terintegrasi kayu dan hasil hutan bukan kayu (agroforestri), dan (vi) komunikasi penyuluhan (Riyandoko et al 2016b). Melalui pelatihan tersebut peserta diharapkan dapat menyebarluaskan informasi yang diperoleh kepada petani dan penyuluh swadaya lainnya. Kesediaan peserta untuk menyebarluaskan informasi dipengaruhi oleh preferensinya terhadap materi pelatihan yang diberikan. Jika peserta menyukai materi yang disampaikan maka ada kecenderungan akan menyebarkan informasi tersebut kepada orang lain. Studi ini bertujuan untuk: (i) mengetahui 
preferensi petani terhadap materi pelatihan, dan (ii) mengetahui proses penyebaran informasi agroforestri yang diperoleh melalui pelatihan.

\section{Metodologi}

\section{II.1 Waktu dan lokasi studi}

Studi mengenai preferensi petani terhadap topik pelatihan dan proses penyebaran informasi dilakukan antara Maret-Juni 2016, yaitu 6-12 bulan setelah pelatihan terhadap penyuluh swadaya dan petani unggul dilakukan. Studi ini dilakukan di lokasi penelitian yang pernah melakukan pelatihan tentang produksi dan pemasaran hasil hutan kayu dan bukan kayu dari sistem agroforestri yang dilakukan oleh the World Agroforestry Centre (ICRAF) melalui proyek Kanoppi, yaitu di Kabupaten Gunungkidul, Daerah Istimewa Yogyakarta; Kabupaten Sumbawa, Provinsi Nusa Tenggara Barat; dan Kabupaten Timor Tengah Selatan, Provinsi Nusa Tenggara Timur (Gambar 1). Setiap lokasi memiliki jenis tanaman kayu dan hasil hutan kayu yang berbeda, selain itu masing-masing lokasi memiliki karakteristik yang saling berbeda dari suku yang dominan dan bahasa sehari-hari yang digunakan oleh petani (Tabel 1.).

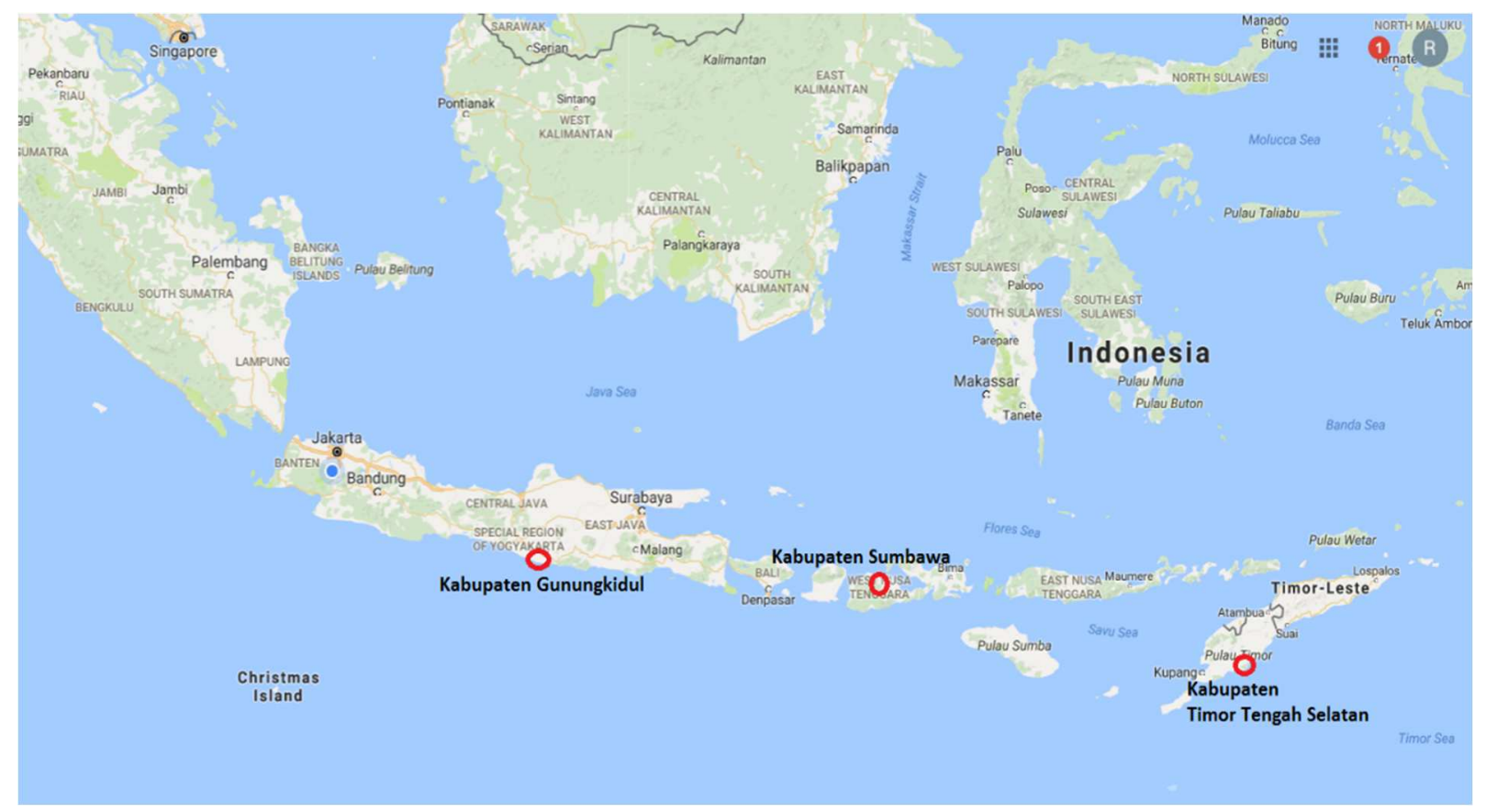

Sumber: Google map, 2016.

Gambar 1. Peta lokasi pelatihan bagi penyuluh swadaya dan petani unggul proyek KANOPPI tahun 2015. 
Tabel 1. Karakteristik lokasi studi di Kabupaten Gunungkidul, Sumbawa dan Timor Tengah Selatan

\begin{tabular}{|c|c|c|c|c|}
\hline \multirow[b]{2}{*}{ Kabupaten, provinsi } & \multicolumn{2}{|c|}{ Jenis tanaman di kebun agroforestri } & \multirow[b]{2}{*}{ Suku dominan } & \multirow{2}{*}{$\begin{array}{l}\text { Bahasa sehari-hari } \\
\text { petani }\end{array}$} \\
\hline & Kayu & $\begin{array}{l}\text { Hasil Hutan Bukan } \\
\text { Kayu }\end{array}$ & & \\
\hline $\begin{array}{l}\text { Gunungkidul, Daerah } \\
\text { Istimewa Yogyakarta }\end{array}$ & $\begin{array}{l}\text { Jati, mahoni, } \\
\text { sengon, sengon laut }\end{array}$ & $\begin{array}{l}\text { Jahe emprit, jahe, } \\
\text { bangle, kunyit. }\end{array}$ & Jawa & Jawa, Indonesia \\
\hline $\begin{array}{l}\text { Sumbawa, Nusa } \\
\text { Tenggara Barat }\end{array}$ & Jati & Kemiri, jahe, madu & Sumbawa & $\begin{array}{l}\text { Indonesia, Sumbawa/ } \\
\text { Samawa }\end{array}$ \\
\hline $\begin{array}{l}\text { Timor Tengah } \\
\text { Selatan }\end{array}$ & Gmelina, mahoni & $\begin{array}{l}\text { Kemiri, jahe, } \\
\text { bambu }\end{array}$ & Mollo, Alor & Mollo \\
\hline
\end{tabular}

Sumber: Data wawancara dengan responden, 2016

\section{II.2 Pengumpulan data}

Pengumpulan data dilakukan melalui wawancara semi terstruktur menggunakan kuisioner terhadap 110 responden yang terdiri dari petani dan penyuluh swadaya di tiga kabupaten dengan jumlah responden perempuan sebesar $29 \%$. Responden dipisahkan menjadi dua yaitu: peserta pelatihan dan non peserta pelatihan. Responden di Sumbawa dan Timor Tengah Selatan adalah petani dan petani unggul, sedangkan responden di Gunungkidul adalah penyuluh swadaya yang telah ditetapkan oleh pemerintah daerah melalui Surat Keputusan Kepala Badan Penyuluhan dan Ketahanan Pangan Gunungkidul. Responden di Kabupaten Sumbawa berjumlah 39 orang berasal dari Desa Pelat dan Desa Batudulang; Kabupaten Timor Tengah Selatan berjumlah 41 orang berasal dari Desa Netpala, Desa Bosen, dan Desa Ajobaki; responden di Kabupaten Gunungkidul sebanyak 30 orang berasal dari Kecamatan Tepus, Girisubo, Semanu, Patuk, Nglipar, Ngawen, Paliyan, Semin, Panggang, Saptosari dan Karangmojo (Tabel 2). Jumlah responden peserta pelatihan berbeda dengan jumlah peserta pelatihan, karena ketika wawancara dalam studi ini dilakukan beberapa peserta sudah tidak berdomisili atau sedang tidak berada di lokasi survei.

Tabel 2. Proporsi jumlah responden di masing-masing kabupaten

\begin{tabular}{lccccc}
\multirow{2}{*}{ Kabupaten } & \multicolumn{2}{c}{ Peserta } & \multicolumn{2}{c}{ Non peserta } & Total \\
\cline { 2 - 6 } & Lelaki & Perempuan & Lelaki & Perempuan & \\
\hline Gunungkidul & 19 & - & 6 & 5 & 30 \\
\hline Sumbawa & 11 & 8 & 15 & 5 & 39 \\
\hline TTS & 13 & 5 & 14 & 9 & 41 \\
\hline
\end{tabular}

Informasi yang dikumpulkan pada studi ini adalah: (i) sumber informasi petani tentang kehutanan dan agroforestri, (ii) penerimaan petani terhadap pengetahuan atau teknologi yang baru diperoleh, (iii) ranking topik pelatihan yang paling menarik menurut peserta pelatihan, dan (iv) masukan responden terhadap pelatihan atau penyuluhan di masa yang akan datang agar lebih memberikan manfaat dan 
dampak. Beberapa pertanyaan yang diajukan kepada peserta berbeda dengan non peserta, misalnya, responden non peserta tidak ditanya tentang tindak lanjut yang dilakukan setelah mengikuti pelatihan.

\section{II.3 Analisa data}

Data yang telah dikumpulkan dianalisa secara kuantitatif dan kualitatif. Analisa statistik Rank Sum Kruskal-Wallis digunakan untuk menganalisa ranking preferensi petani terhadap topik pelatihan yang diterima, dan dilanjutkan dengan analisa kualitatif dari faktor-faktor pendukung preferensi petani. Analisa Jaringan Sosial digunakan untuk menganalisa penyebaran informasi agroforestri dan kehutanan. Analisa data pada studi ini menggunakan perangkat lunak SYSTAT 11 untuk analisa Kruskal-Wallis dan Node XL untuk analisa jaringan sosial.

\section{Hasil dan Pembahasan}

\section{III.1 Pelatihan bagi penyuluh swadaya dan petani unggul}

Pelatihan bagi penyuluh swadaya dan petani unggul dilaksanakan pada tahun 2015 di Sumbawa, Timor Tengah Selatan dan Gunungkidul yang diikuti oleh 73 orang, dengan peserta perempuan sebanyak 26\% (Tabel 3). Peserta yang menghadiri pelatihan di Sumbawa dan Timor Tengah Selatan adalah petani dan petani unggul yang direkomendasikan oleh kelompok tani, pemerintah desa dan balai penyuluhan kecamatan. Petani unggul adalah petani yang memiliki pengalaman dan pengetahuan lebih dari petani lainnya yang diproyeksikan sebagai penyuluh swadaya oleh badan pelaksana penyuluhan setempat. Jumlah petani yang mengikuti pelatihan sebanyak 49 orang, dengan petani perempuan sebesar 32,7\%. Peserta pelatihan di Gunungkidul adalah penyuluh swadaya yang telah ditetapkan melalui surat keputusan kepala badan penyuluhan kabupaten sejumlah 19 orang. Penyuluh pemerintah yang mengikuti pelatihan adalah penyuluh kehutanan, penyuluh pertanian dan petugas lapangan Kesatuan Pengelolaan Hutan (KPH) di masing-masing lokasi, yang berjumlah 15 orang.

Topik yang dipelajari dalam pelatihan yaitu: (a) pengantar tentang kayu dan hasil hutan bukan kayu, (b) kebijakan yang terkait dengan penatausahaan hasil hutan hak milik, (c) pemasaran kayu dan hasil hutan bukan kayu, (d) pemeliharaan tanaman kayu (silvikultur), (e) pengelolaan kebun yang terintegrasi antara kayu dan hasil hutan bukan kayu, dan (f) komunikasi penyuluhan dan penyebaran informasi (Silabus dapat dilihat pada Lampiran 1.). Berdasarkan silabus, semua topik materi pelatihan dipelajari selama empat hari, namun dalam pelaksanaannya disesuaikan dengan kesepakatan awal dan kontrak belajar antara peserta dan fasilitator. Di Sumbawa dan Gunungkidul pelatihan dilaksanakan selama empat hari, sedangkan di Timor Tengah Selatan dilaksanakan selama tiga hari. Pengurangan hari di Timor Tengah Selatan dilakukan atas kesepakatan bersama antara peserta dan fasilitator, 
dengan alasan ada satu hari yang bersamaan dengan hari pasar. Pada saat hari pasar petani biasanya melakukan transaksi jual beli untuk memenuhi kebutuhan hariannya.

Tabel 3. Jumlah peserta pelatihan tentang kayu dan hasil hutan bukan kayu bagi penyuluh swadaya dan petani unggul di Gunungkidul, Sumbawa, dan Timor tengah Selatan.

\begin{tabular}{|c|c|c|c|c|c|c|c|}
\hline \multirow{3}{*}{ Kabupaten } & \multirow{3}{*}{ Waktu (durasi) } & \multicolumn{6}{|c|}{ Jumlah Peserta } \\
\hline & & \multicolumn{2}{|c|}{ Petani } & \multicolumn{2}{|c|}{ Penyuluh swadaya } & \multicolumn{2}{|c|}{ Penyuluh Pemerintah } \\
\hline & & $\mathbf{L}$ & $\mathbf{P}$ & $\mathbf{L}$ & $\mathbf{P}$ & $\mathbf{L}$ & $\mathbf{P}$ \\
\hline Sumbawa & $\begin{array}{l}\text { 11-14 Mei } 2015 \\
\text { (empat hari) }\end{array}$ & 11 & 10 & 0 & 0 & 3 & 1 \\
\hline $\begin{array}{l}\text { Timor Tengah } \\
\text { Selatan }\end{array}$ & $\begin{array}{l}\text { 20-22 Oktober } 2015 \\
\text { (tiga hari) }\end{array}$ & 12 & 6 & 0 & 0 & 4 & 2 \\
\hline Gunungkidul & $\begin{array}{l}\text { 14-17 Desember } 2015 \\
\text { (empat hari) }\end{array}$ & 0 & 0 & 19 & 0 & 5 & 0 \\
\hline
\end{tabular}

Sumber: Data laporan kegiatan pelatihan, 2015. Catatan: $L=l e l a k i ; P=P e r e m p u a n$

Pelaksanaan pelatihan di masing-masing lokasi terselenggara atas kerjasama dengan lembaga pemerintah maupun lembaga swadaya masyarakat (LSM) setempat, yaitu:

a. Pelatihan di Sumbawa diselenggarakan atas kerjasama Kanoppi dengan WWF Indonesia program Nusa Tenggara, Balai Penelitian dan Teknologi Hasil Hutan Bukan Kayu (BPTHHBK) Mataram, Universitas Mataram, dan Badan Pelaksana Penyuluhan Pertanian, Perikanan dan Kehutanan (BP4K) Kabupaten Sumbawa;

b. Pelatihan di Timor Tengah Selatan diselenggarakan atas kerjasama Kanoppi dengan Badan Penyuluhan dan Dinas Kehutanan;

c. Penyelenggaraan pelatihan di Gunungkidul atas kerjasama Kanoppi dengan Dinas Kehutanan dan Perkebunan Gunungkidul, dan Badan Pelaksana Penyuluhan Kabupaten Gunungkidul.

\section{III.2 Preferensi petani terhadap topik pelatihan agroforestri}

Pada studi ini, preferensi atau kesukaan petani terhadap topik penyuluhan dilihat dari ranking materi pelatihan yang paling menarik menurut responden kategori peserta pelatihan. Hasil analisa KruskalWallis menunjukkan bahwa ranking preferensi responden terhadap materi pelatihan dari semua wilayah secara berurutan dari yang paling disukai sebagai berikut: (1) pemeliharaan tanaman kayu (silvikultur), (2) pengelolaan kebun terintegrasi antara kayu dan hasil hutan bukan kayu, (3) pemasaran hasil hutan kayu dan hasil hutan bukan kayu, (4) kebijakan yang berkaitan dengan penatausahaan hasil hutan hak, (5) komunikasi penyuluhan, dan (6) pengantar kayu dan hasil hutan bukan kayu (HHBK).

Kesukaan responden terhadap topik materi pelatihan dipengaruhi oleh kebutuhan mereka terhadap materi pelatihan dan penyuluhan terkait praktik-praktik berkebun yang mendasar. Dari keenam materi 
tersebut topik pemeliharaan tanaman kayu (silvikultur) dan pengolahan kebun terintegrasi antara kayu dan hasil hutan bukan kayu (agroforestri) merupakan topik praktis mengenai cara berkebun, yang menjadi kebutuhan dasar petani dalam bekerja di kebun.

Pada analisa lanjutan terlihat bahwa selain kebutuhan akan ilmu praktis dan mendasar, kesukaan petani terhadap topik pelatihan juga dipengaruhi oleh faktor wilayah dan peran gender. Petani lelaki di ketiga kabupaten cenderung menyukai topik pelatihan yang sama yaitu: pemeliharaan tanaman kayu (silvikultur), diikuti dengan topik pengelolaan kebun yang terintegrasi antara kayu dan HHBK (agroforestri), dan pemasaran hasil kayu dan hasil hutan bukan kayu. Sementara, preferensi petani perempuan terhadap topik pelatihan berbeda antar lokasi (Tabel 4.).

Tabel 4. Preferensi petani terhadap topik pelatihan agroforestri.

\begin{tabular}{|c|c|c|c|c|c|c|}
\hline \multirow{2}{*}{ Ranking* } & \multicolumn{2}{|c|}{ Sumbawa } & \multicolumn{2}{|c|}{ Gunungkidul } & \multicolumn{2}{|c|}{ Timor Tengah Selatan } \\
\hline & Lelaki & Perempuan & Lelaki & Perempuan & Lelaki & Perempuan \\
\hline 1 & Silvikultur & $\begin{array}{l}\text { Pengelolaan } \\
\text { integrasi kayu } \\
\text { dan HHBK }\end{array}$ & Silvikultur & - & Silvikultur & Silvikultur \\
\hline 2 & $\begin{array}{l}\text { Pengelolaan } \\
\text { kebun } \\
\text { integrasi kayu } \\
\text { dan HHBK }\end{array}$ & Silvikultur & $\begin{array}{l}\text { Pengelolaan } \\
\text { kebun } \\
\text { integrasi } \\
\text { kayu dan } \\
\text { HHBK }\end{array}$ & - & $\begin{array}{l}\text { Pengelolaan } \\
\text { kebun integrasi } \\
\text { kayu dan } \\
\text { HHBK }\end{array}$ & $\begin{array}{l}\text { Pemasaran / } \\
\text { kebijakan } \\
\text { penata- } \\
\text { usahaan } \\
\text { hasil hutan } \\
\text { hak }\end{array}$ \\
\hline 3 & Pemasaran & Pemasaran & Pemasaran & - & Pemasaran & - \\
\hline 4 & $\begin{array}{l}\text { Pengantar } \\
\text { kayu dan } \\
\text { HHBK }\end{array}$ & $\begin{array}{l}\text { Kebijakan } \\
\text { penatausahaa } \\
\mathrm{n} \text { hasil hutan } \\
\text { hak }\end{array}$ & $\begin{array}{l}\text { Kebijakan } \\
\text { penatausaha } \\
\text { an hasil } \\
\text { hutan hak }\end{array}$ & - & $\begin{array}{l}\text { Kebijakan } \\
\text { penatausahaa } \\
\mathrm{n} \text { hasil hutan } \\
\text { hak }\end{array}$ & $\begin{array}{l}\text { Pengelolaan } \\
\text { kebun } \\
\text { integrasi } \\
\text { kayu dan } \\
\text { HHBK }\end{array}$ \\
\hline 5 & $\begin{array}{l}\text { Kebijakan } \\
\text { penatausahaa } \\
\mathrm{n} \text { hasil hutan } \\
\text { hak }\end{array}$ & $\begin{array}{l}\text { Pengantar } \\
\text { Kayu dan } \\
\text { HHBK }\end{array}$ & $\begin{array}{l}\text { Komunikasi } \\
\text { penyuluhan }\end{array}$ & - & $\begin{array}{l}\text { Komunikasi } \\
\text { penyuluhan }\end{array}$ & $\begin{array}{l}\text { Pengantar } \\
\text { kayu dan } \\
\text { HHBK }\end{array}$ \\
\hline 6 & $\begin{array}{l}\text { Komunikasi } \\
\text { penyuluhan }\end{array}$ & $\begin{array}{l}\text { Komunikasi } \\
\text { penyuluhan }\end{array}$ & $\begin{array}{l}\text { Pengantar } \\
\text { kayu dan } \\
\text { HHBK }\end{array}$ & - & $\begin{array}{l}\text { Pengantar } \\
\text { kayu dan } \\
\text { HHBK }\end{array}$ & $\begin{array}{l}\text { Komunikasi } \\
\text { penyuluhan }\end{array}$ \\
\hline
\end{tabular}

Sumber: Data primer; keterangan: * ranking 1 adalah yang paling disukai

Peserta perempuan cenderung menyukai topik pelatihan sesuai dengan kebiasaan sehari-hari. Petani perempuan di Timor Tengah Selatan yang lebih jarang bekerja di kebun menyukai materi pemasaran atau kebijakan penatausahaan hasil hutan hak milik dan pemeliharaan tanaman kayu. Sementara, petani perempuan di Sumbawa yang biasa bekerja di kebun lebih menyukai topik mengenai pengelolaan kebun terintegrasi kayu dan bukan kayu (agroforestri), terutama penanaman tanaman sela di bawah tegakan pohon, seperti jahe di bawah tegakan tanaman jati. Di Kabupaten Gunungkidul, tidak ada peserta perempuan dalam pelatihan karena tidak ada penyuluh kehutanan maupun penyuluh swadaya kehutanan yang perempuan di kabupaten ini. Selain itu berdasarkan observasi di lapangan 
dan diskusi dengan petani ada persepsi bahwa bidang agroforestri ataupun kehutanan bukan prioritas kaum perempuan.

\section{III.3 Proses Penyebaran Informasi Agroforestri}

\section{III.3.1 Sumber-sumber informasi tentang agroforestri dan kehutanan}

Hasil studi menujukkan bahwa sumber-sumber informasi petani tentang agroforestri dan kehutanan berasal dari: (i) luar desa, (ii) dalam desa, dan (iii) media elektronik dan cetak. Sumber informasi dari luar desa yaitu: penyuluh, lembaga pemerintah, lembaga non pemerintah (LSM) dan lembaga swasta. Sumber informasi dari dalam desa berasal dari keluarga, teman, tetangga, kelompok tani dan petani unggul. Dalam studi ini sumber informasi petani tentang agroforestri dan kehutanan disajikan dalam diagram jaringan sosial. Diagram ini berisikan bentuk simbol yang menggambarkan sumber informasi dan garis-garis yang menggambarkan alur penyebaran dan keterkaitan antar sumber informasi. Bentuk simbol yang digunakan dalam artikel ini adalah lingkaran, segitiga dan persegi. Ukuran bentuk simbol menunjukkan peran dan pengaruh dari sumber informasi terhadap petani. Semakin besar ukuran bentuk simbol menunjukkan peran dan pengaruh yang semakin besar pula.

Sumber informasi tentang agroforestri dan kehutanan yang paling berperan dan berpengaruh terhadap petani di ketiga lokasi studi adalah sumber informasi yang berasal dari luar desa yaitu penyuluh, Dinas Kehutanan Kabupaten dan lembaga non pemerintah (LSM) dan proyek kehutanan. Sementara, sumber informasi dari dalam desa yang paling berperan dan pengaruh terhadap pengetahuan petani tentang agroforestri dan kehutanan adalah keluarga, kelompok tani dan petani unggul.

Jika dilihat dari sudut pandang gender, terdapat perbedaan sumber informasi yang dijadikan sebagai acuan dari masing-masing gender untuk memperoleh informasi tentang agroforestri dan kehutanan. Sumber informasi yang memiliki peran besar terhadap petani perempuan adalah keluarga, kelompok tani dan lembaga non pemerintah seperti LSM, sedangkan sumber informasi yang berperan besar terhadap petani lelaki adalah penyuluh, Dinas Kehutanan Kabupaten dan lembaga bukan pemerintah (Gambar 2). Sumber informasi bagi petani perempuan cenderung berasal dari dalam desa, sedangkan bagi petani lelaki berasal dari luar desa. Kecenderungan ini terjadi karena petani lelaki lebih sering mendapat kesempatan untuk berhubungan dengan pihak luar desa dibanding petani perempuan. Sebagai contoh petani lelaki cenderung dikirim untuk menghadiri undangan pelatihan atau penyuluhan di luar desa seperti di tingkat kabupaten, provinsi dan nasional, sedangkan kesempatan bagi petani perempuan untuk mengikuti pelatihan di luar desa relatif kecil sehingga sumber informasi cenderung berasal dari keluarga, kelompok tani dan petani unggul yang mengikuti pelatihan. Kecenderungan petani perempuan mengakses informasi melalui media elektronik lebih besar dibanding petani lelaki karena di siang hari mereka cenderung berada di rumah dan menonton televisi. 


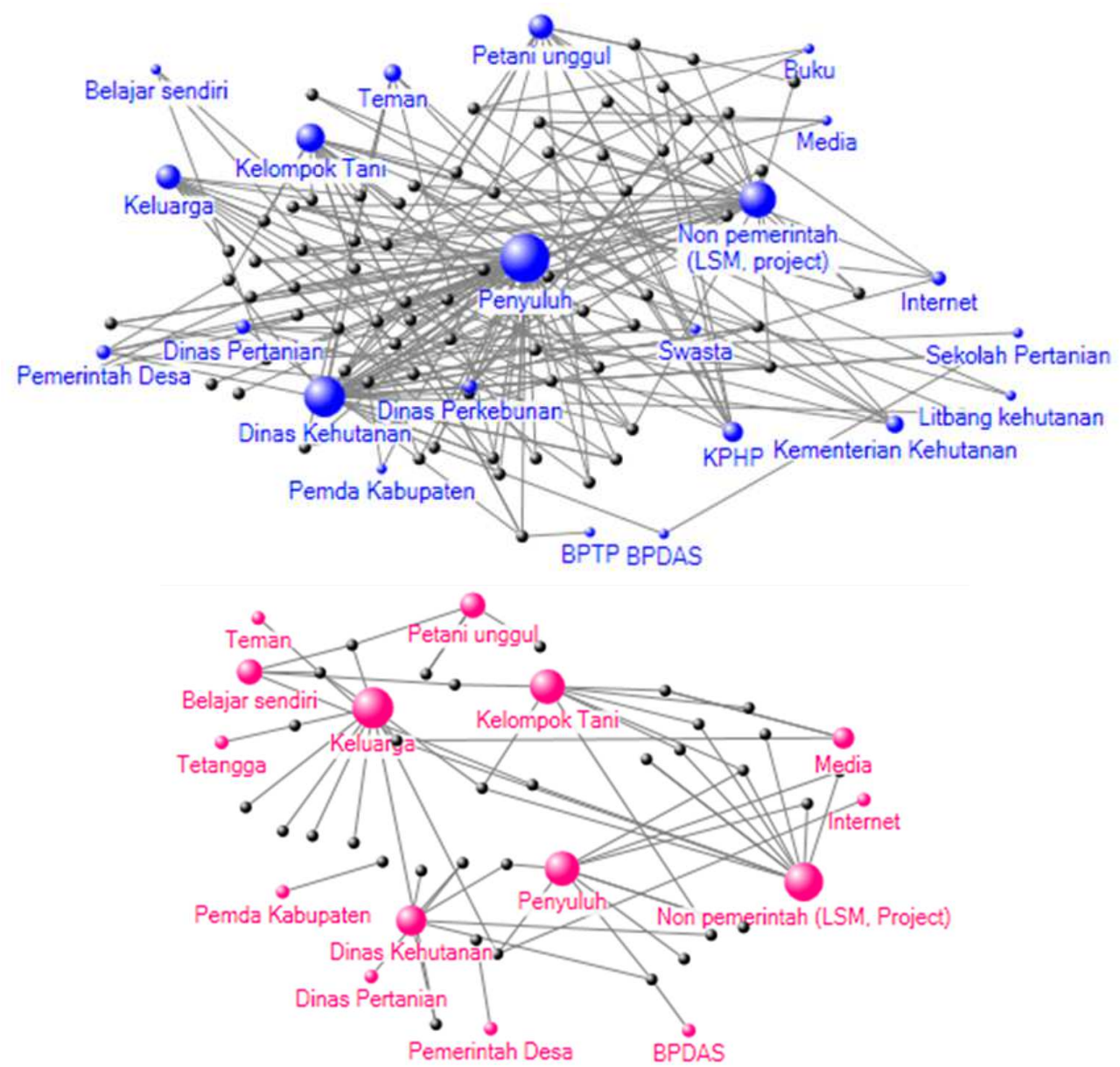

Gambar 2. Diagram jaringan sumber-sumber informasi tentang agroforestri dan kehutanan di semua kabupaten lokasi studi berdasarkan perbedaan gender.

Perbedaan prioritas sumber-sumber informasi agroforestri dan kehutanan juga ditemukan di antara ketiga kabupaten (Gambar 3). Di Gunungkidul, penyuluh, Dinas Kehutanan Kabupaten dan lembaga non pemerintah adalah sumber utama informasi tentang agroforestri dan kehutanan. Sementara di Sumbawa, petani unggul, lembaga non pemerintah, Kesatuan Pengelolaan Hutan Produksi (KPHP) dan penyuluh adalah sumber informasi yang paling sering diakses petani, sedangkan di Timor Tengah Selatan, penyuluh, kelompok tani dan keluarga adalah sumber informasi utama bagi petani tentang agroforestri dan kehutanan. Di Timor Tengah Selatan, keterbatasan petani untuk mengakses informasi dari luar desa mengakibatkan ketergantungan terhadap informasi dari dalam desa seperti kelompok tani dan keluarga. Keduanya memiliki peran penting dalam penyebaran informasi agroforestri dan kehutanan. Di Gunungkidul, keluarga sama sekali tidak menjadi sumber informasi mengenai agroforestri dan kehutanan.

Jumlah sumber informasi di Gunungkidul lebih banyak dibandingkan di Sumbawa dan Timor Tengah Selatan. Bahkan hanya di Gunungkidul ditemukan bahwa Kementrian Kehutanan dan Puslitbang (Pusat Penelitian dan Pengembangan) kehutanan memiliki peran sebagai sumber informasi mengenai agroforestri dan kehutanan. Timor Tengah Selatan memiliki jumlah sumber informasi paling sedikit, 
karena terbatasnya lembaga yang memfokuskan kegiatan di bidang agroforestri dan kehutanan di Timor Tengah Selatan, jika dibandingkan dengan di Gunungkidul dan Sumbawa.
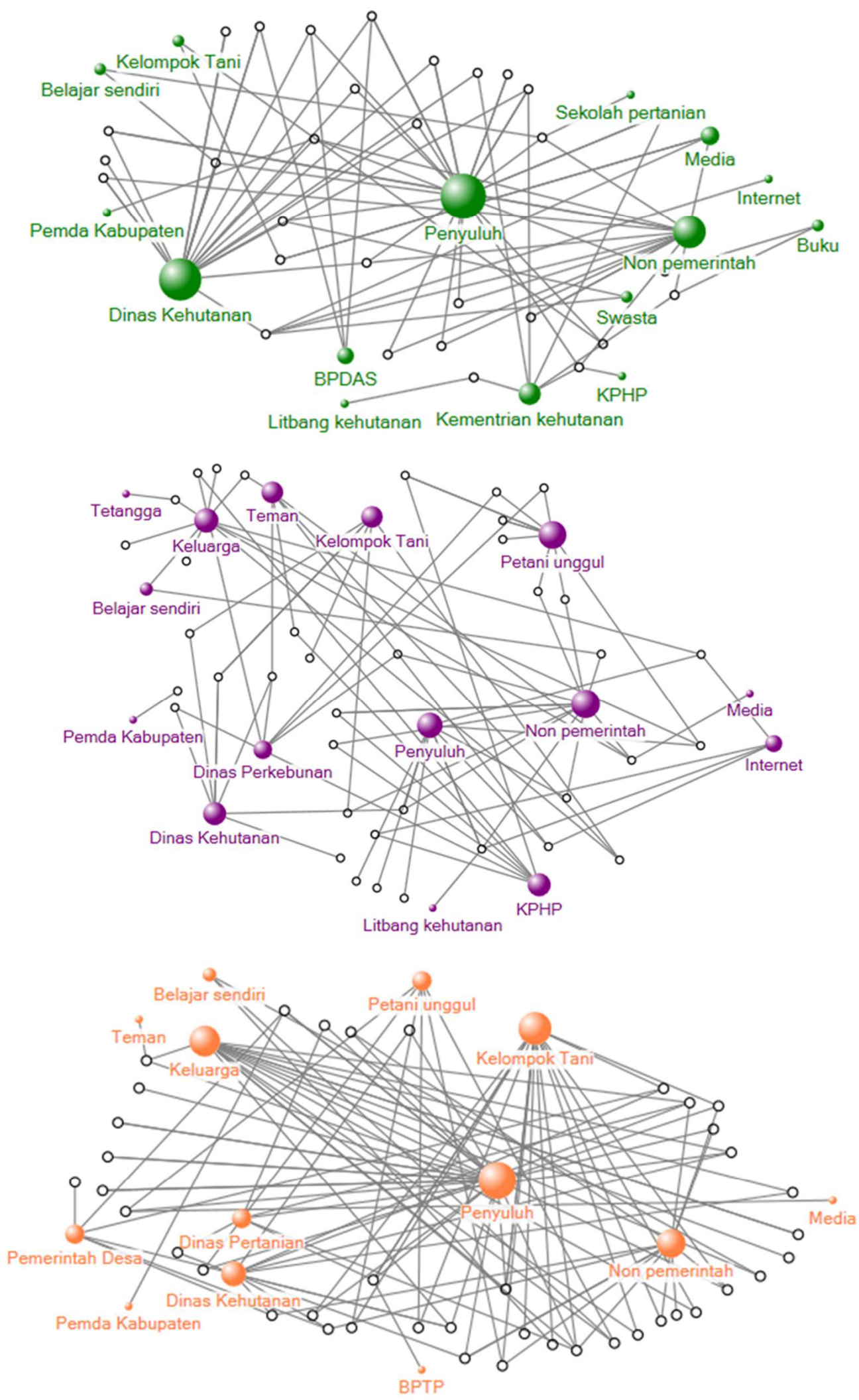

Gambar 3. Perbedaan prioritas sumber-sumber informasi agroforestri dan kehutanan antara Kabupaten Gunungkidul, Sumbawa, dan Timor Tengah Selatan. 


\section{III.3.1.1 Sumber informasi tentang agroforestri dan kehutanan bagi petani di Gunungkidul berdasarkan perbedaan gender}

Di Gunungkidul, penyuluhan ataupun pelatihan tentang agroforestri dan kehutanan lebih banyak diprioritaskan pada kaum lelaki, hanya kaum perempuan yang berperan penting di masyarakat seperti ketua kelompok tani wanita dan kepala desa yang mengikuti pelatihan. Selain itu, ada persepsi di masyarakat bahwa kegiatan agroforestri dan kehutanan adalah bidang bagi kaum lelaki, sehingga kaum perempuan tidak terlalu aktif mencari informasi yang terkait dengan hal tersebut. Hal ini mengakibatkan lebih sedikitnya jumlah sumber informasi yang digunakan oleh kaum perempuan dalam mencari informasi tentang agroforestri dan kehutanan.

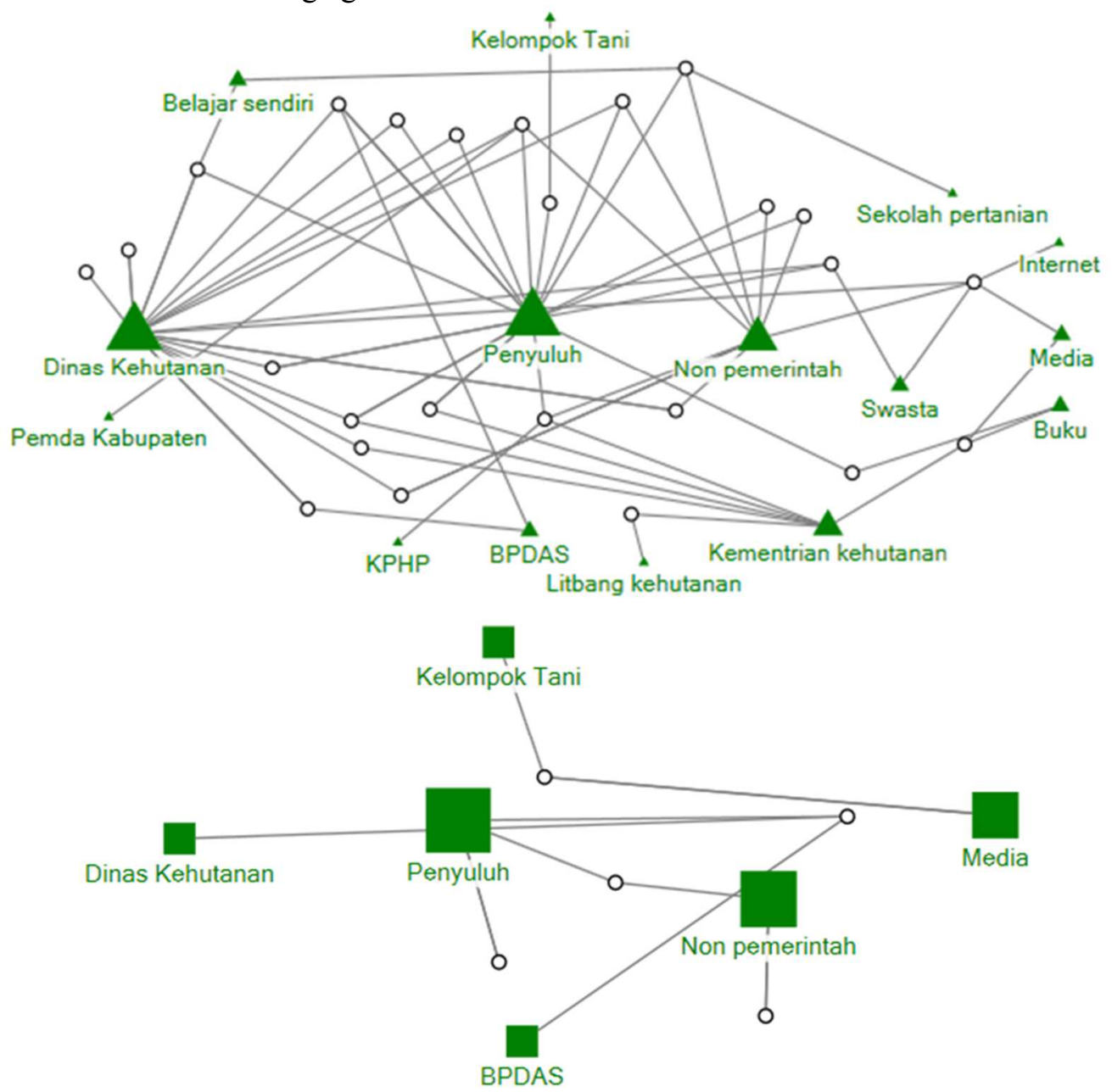

Gambar 4. Diagram jaringan sosial sumber informasi tentang agroforestri dan kehutanan bagi petani lelaki dan perempuan di Gunungkidul.

Baik bagi perempuan maupun lelaki, penyuluh dan lembaga non pemerintahan menjadi sumber utama untuk mencari informasi agroforestri dan kehutanan (Gambar 4). Perbedaan prioritas sumber informasi antara lelaki dan perempuan di Gunungkidul terjadi karena kelompok tani dan media memiliki peran yang lebih kuat bagi perempuan, sedangkan program-program dari Kementerian Kehutanan lebih berperan sebagai sumber informasi agroforestri bagi kaum lelaki. Berbeda dengan 
kaum perempuan, petani lelaki di Gunungkidul selain memiliki akses lebih tinggi terhadap sumber informasi di tingkat kabupaten juga di tingkat nasional. Kemudahan akses terhadap sumber informasi ke tingkat nasional ini diperoleh oleh beberapa petani yang berperan sebagai penyuluh swadaya. Sebagai bentuk peningkatan kapasitas, mereka dikirim untuk mengikuti pendidikan dan pelatihan yang diselenggarakan di tingkat nasional.

\section{III.3.1.2 Sumber informasi tentang agroforestri dan kehutanan bagi petani di Sumbawa berdasarkan perbedaan gender}

Petani di Sumbawa mendapatkan informasi tentang agroforestri dan kehutanan dari sumber informasi dari luar desa dan dalam desa secara seimbang. Lembaga non pemerintah (LSM), penyuluh, dinas kehutanan dan kesatuan pengelolaan hutan produksi (KPHP) Batulanteh merupakan sumber informasi penting dari luar desa, sedangkan sumber informasi dari dalam desa berasal adalah petani unggul, keluarga, kelompok tani dan teman. Petani di Sumbawa cenderung kurang dalam mengakses informasi dari media elektronik dan internet karena keterbatasan sarana dan prasarana. Peran sumber informasi dari luar dan dalam desa yang seimbang di Sumbawa dipengaruhi oleh letak lokasi yang tidak terlalu jauh dari pusat pemerintahan kabupaten, sehingga penyuluh, Dinas Kehutanan dan LSM dapat mengakses lokasi dengan mudah. Komunikasi antar individu di dalam keluarga, kelompok tani dan tetangga mendukung penyebaran informasi yang lebih baik.

Sumber informasi yang berperan besar terhadap petani perempuan di Sumbawa berasal dari dalam desa yaitu: keluarga, petani unggul, kelompok tani, tetangga dan teman (Gambar 5). Keluarga masih memegang peranan penting sebagai sumber informasi, diikuti oleh petani unggul dan kelompok tani, sedangkan sumber informasi penting yang berasal dari luar desa yang lebih berpengaruh terhadap petani perempuan adalah lembaga non pemerintah (LSM) dibandingkan penyuluh atau lembaga pemerintah.

Sumber informasi yang berasal dari dalam desa dan luar desa berperan seimbang bagi petani lelaki di Sumbawa. Sumber informasi dari luar desa yang berperan besar yaitu: penyuluh, lembaga non pemerintah dan KPHP Batulanteh, sedangkan sumber informasi dari dalam desa yang berperan besar yaitu: petani unggul, kelompok tani dan teman. Dari hasil studi terlihat bahwa petani perempuan cenderung memanfaatkan internet dan media elektronik sebagai sumber informasi dibanding petani lelaki. 

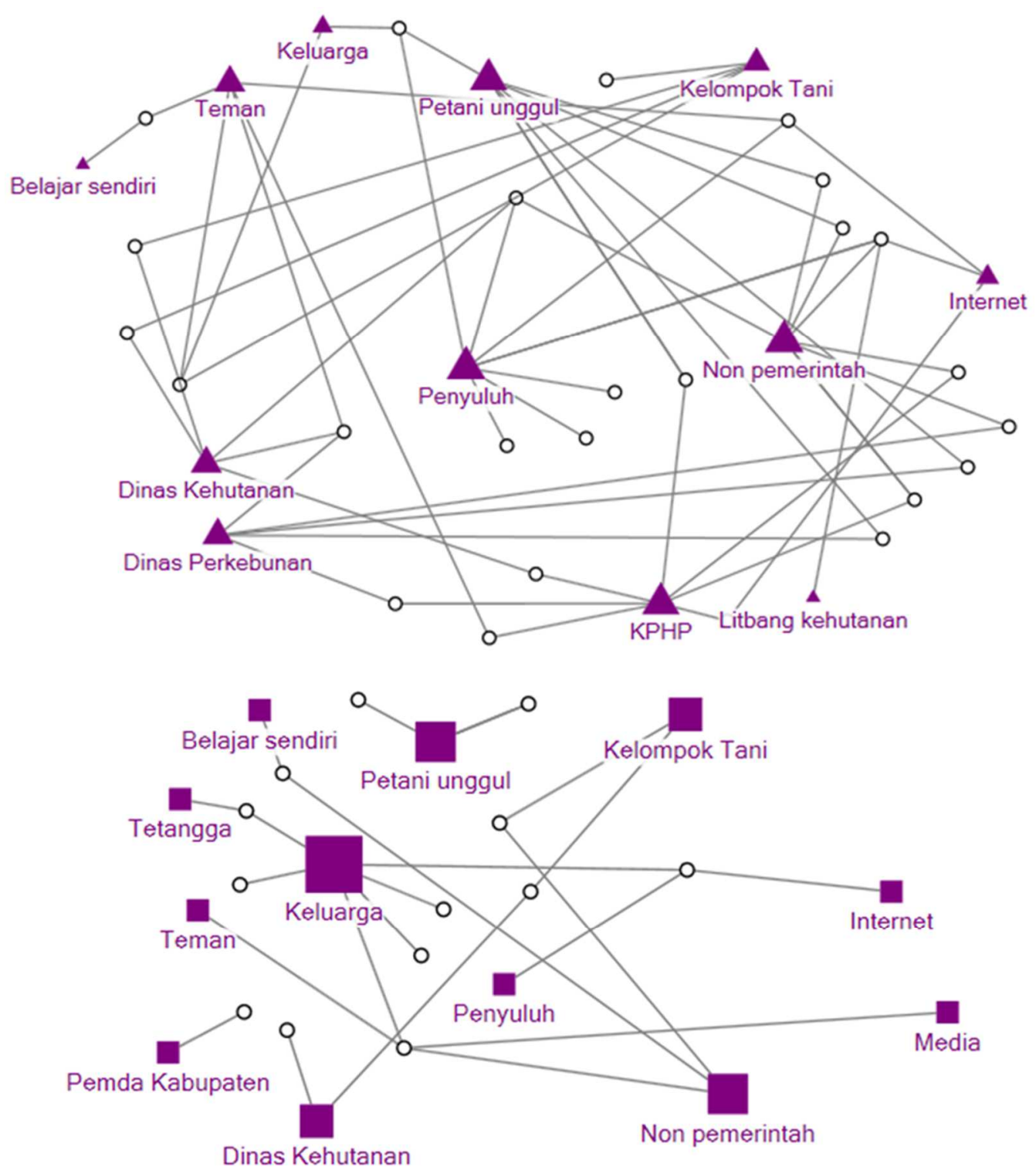

Gambar 5. Diagram jaringan sosial sumber informasi tentang agroforestri dan kehutanan bagi petani lelaki dan perempuan di Sumbawa.

\section{III.3.1.3 Sumber informasi tentang agroforestri dan kehutanan bagi petani di Timor Tengah Selatan berdasarkan perbedaan gender}

Di Timor Tengah Selatan, penyuluh memegang peranan besar sebagai sumber informasi petani, begitu pula peran dari keluarga dan kelompok tani, terutama ketika petani memiliki interaksi yang minim dengan penyuluh. Hal ini terjadi di Desa Bosen dan Desa Ajobaki yang lokasinya relatif jauh dan terpencil, sehingga penyuluh jarang mengunjungi desa tersebut.

Sumber informasi dari dalam desa seperti keluarga dan kelompok tani memiliki peran lebih besar bagi petani perempuan di Timor Tengah Selatan dibanding sumber informasi yang berasal dari luar desa. (Gambar 6). Selain dari dua sumber tersebut petani perempuan di Timor Tengah Selatan mengakses informasi dari pemerintah desa dan petani unggul, sedangkan dari luar desa sumber informasi petani 
perempuan berasal dari penyuluh, Dinas Kehutanan, lembaga bukan pemerintah yang memiliki peran seimbang. Kesempatan petani perempuan mengikuti pelatihan dan penyuluhan belum merata terutama bagi petani yang tinggal di daerah terpencil.

Lelaki di Timor Tengah Selatan lebih cenderung memperoleh informasi tentang agroforestri dan kehutanan dari sumber yang berasal dari luar desa, meskipun sumber informasi dari dalam desa seperti keluarga dan kelompok tani juga memiliki peran besar. Penyuluh masih menjadi sumber informasi paling berpengaruh bagi petani lelaki, karena petani lelaki lebih sering mendapatkan kesempatan mengikuti kegiatan penyuluhan yang dilakukan di desa maupun di luar desa.
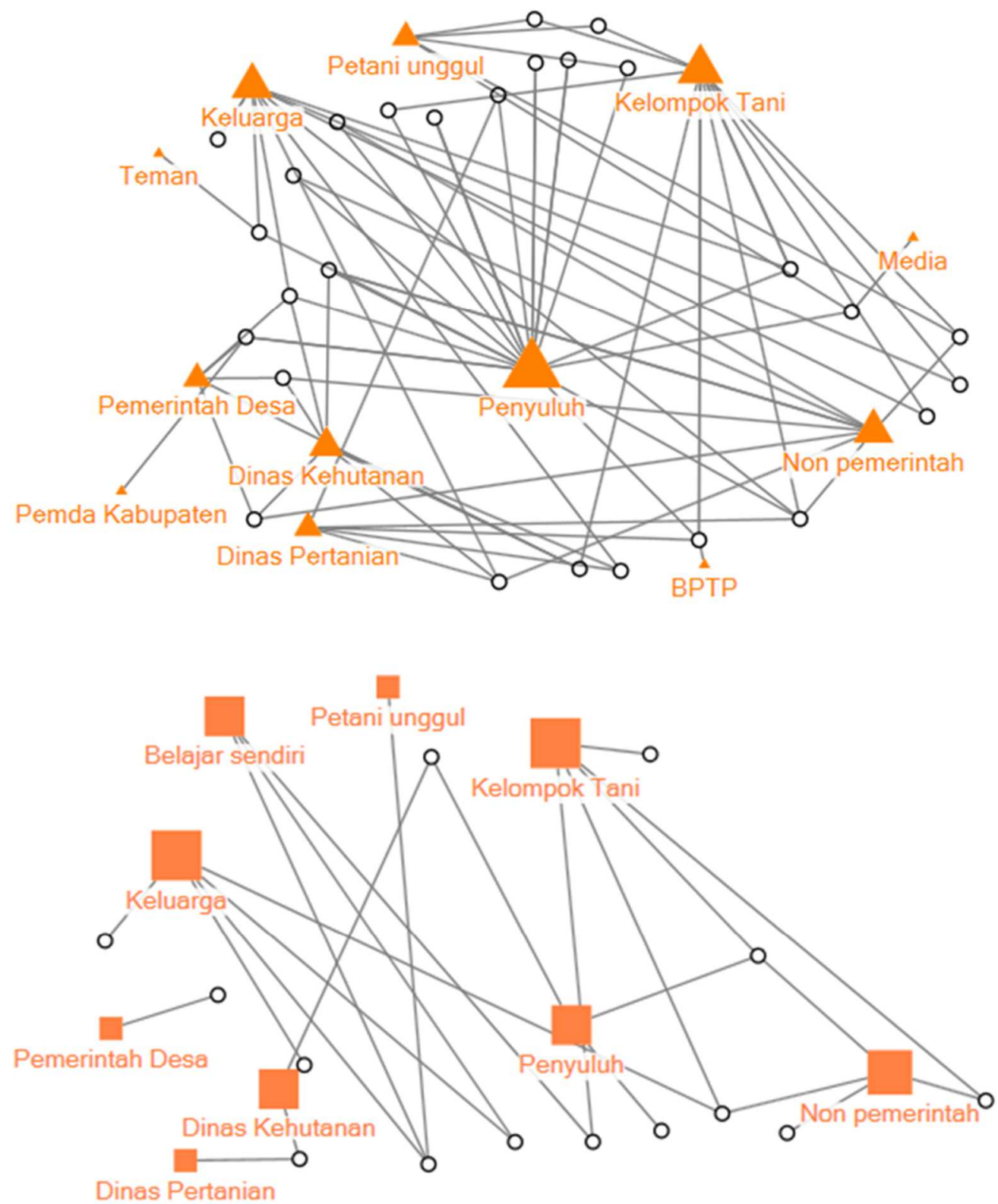

Gambar 6. Diagram jaringan sosial sumber informasi tentang agroforestri dan kehutanan bagi petani lelaki dan perempuan di Timor Tengah Selatan. 


\section{III.3.2 Penyebaran informasi agroforestri dan kehutanan hasil dari pelatihan yang dilakukan oleh Kanoppi}

Pada bagian ini penyebaran informasi yang dianalisa adalah berdasarkan topik penyuluhan agroforestri dan kehutanan yang diterima oleh petani yaitu: (i) Kayu dan hasil hutan bukan kayu (HHBK); (ii) Pemasaran kayu dan hasil hutan bukan kayu; (iii) Kebijakan dan penatausahaan hasil hutan hak milik; (iv) Silvikultur; dan (v) Pengelolaan kebun agroforestri. Analisa dilakukan dari respon jawaban yang diperoleh dari responden yang bukan peserta pelatihan, terutama tentang sumber informasi yang pernah mereka akses yang berkaitan dengan topik-topik tersebut di atas.

\section{III.3.2.1 Penyebaran informasi tentang topik kayu dan hasil hutan bukan kayu}

Penyebaran informasi tentang topik kayu dan hasil hutan bukan kayu, terutama tentang definisi dan jenis-jenis produk yang dikategorikan sebagai kayu dan bukan kayu, Dinas Kehutanan memiliki peran yang paling penting dibandingkan aktor penyebar informasi lainnya. Informasi yang disampaikan dari kegiatan Kanoppi paling banyak diterima oleh petani melalui Dinas Kehutanan (Gambar 7), sehingga kegiatan penyuluhan ataupun pelatihan yang berkaitan dengan penyebaran informasi tentang definisi dan jenis-jenis produk kayu dan bukan kayu sebaiknya melibatkan Dinas Kehutanan sebagai peserta sehingga mereka dapat membantu menyebarkan informasi yang diberikan melalui penyuluhan dan pelatihan ke petani yang membutuhkannya.

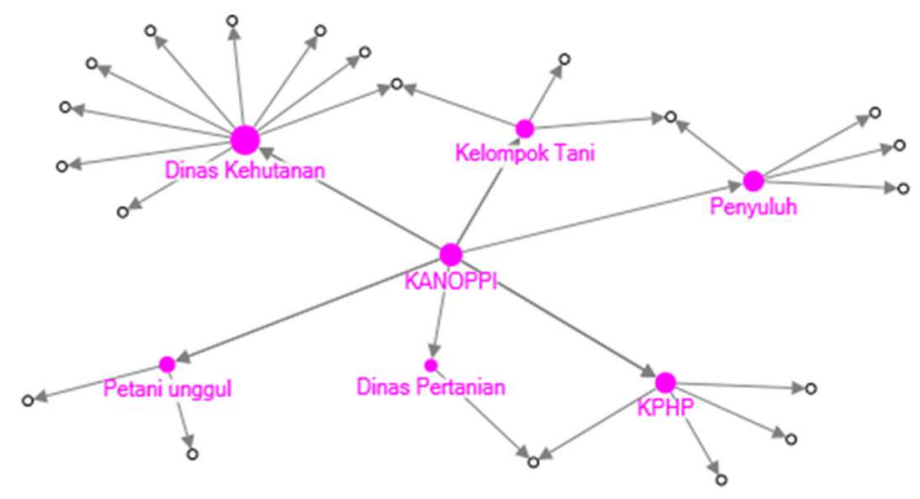

Gambar 7. Diagram jaringan sosial sumber informasi petani pada topik kayu dan hasil hutan bukan kayu

\section{III.3.2.1 Penyebaran informasi tentang topik pemasaran kayu dan hasil hutan bukan kayu}

Pada topik pemasaran kayu dan hasil hutan bukan kayu, Kanoppi memberikan informasi tentang bagaimana cara memasarkan kayu, kualitas kayu dan non kayu yang diinginkan oleh pasar, serta harga yang diperoleh dari produk dengan kualitas yang berbeda-beda. Informasi yang disampaikan oleh Kanoppi diterima oleh petani yang bukan peserta pelatihan terutama dari pedagang kayu dan produk non kayu yang terlibat dalam kegiatan pelatihan Kanoppi tersebut (Gambar 8). Hal ini menunjukkan bahwa penyuluhan ataupun pelatihan yang bertujuan untuk meningkatkan pengetahuan petani tentang pemasaran kayu dan non kayu perlu melibatkan pedagang karena memiliki potensi 
yang cukup besar sebagai penyebar informasi. Bagi pedagang sendiri, melakukan penyuluhan terhadap petani dapat dijadikan sebagai strategi menghasilkan produk kayu dan produk non kayu yang lebih baik.

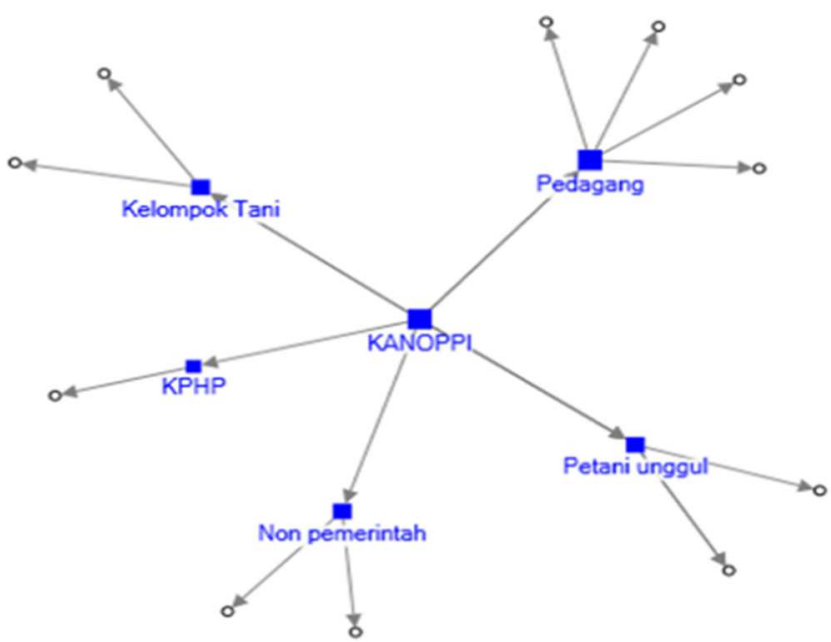

Gambar 8. Diagram jaringan sosial sumber informasi petani pada topik pemasaran kayu dan hasil hutan bukan kayu

\section{III.3.2.3 Penyebaran informasi tentang topik kebijakan penatausahaan hasil hutan hak milik}

Informasi tentang kebijakan penatausahaan hasil hutan hak milik, terutama tentang perijinan untuk penggunaan kayu dan penjualan produk kayu dari kebun telah disebarkan oleh Kanoppi melalui pelatihan diterima oleh responden non peserta pelatihan dari pemerintah desa, dalam hal ini kepala desa beserta aparatnya (Gambar 9). Hal ini terjadi karena pemerintah desa memiliki peran penting dalam memberikan ijin untuk pemanenan dan penjualan kayu dari kebun ataupun hutan rakyat yang berada di dalam wilayah desanya. Oleh karena itu dalam kegiatan sosialisasi tentang kebijakan penatausahaan hasil hutan hak milik sebaiknya melibatkan pemerintah desa sebagai penyebar informasi.

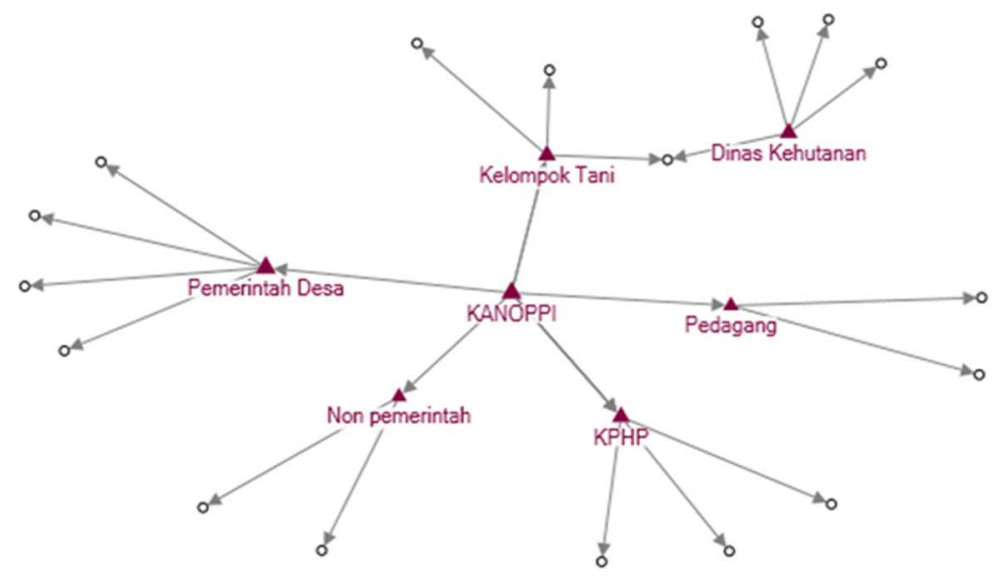

Gambar 9. Diagram jaringan sosial sumber informasi petani pada topik kebijakan terkait penatausahaan hasil hutan hak milik 


\section{III.3.2.4 Penyebaran informasi tentang topik silvikultur}

Topik silvikultur yang dibahas pada pelatihan yang dilakukan oleh Kanoppi adalah tentang penjarangan dan pemangkasan tanaman kayu khususnya jati. Informasi yang disebarkan oleh Kanoppi melalui pelatihan tentang hasil hutan kayu dan non kayu, lebih banyak diterima oleh responden non peserta pelatihan dari Dinas Kehutanan dan penyuluh (Gambar 10). Hal ini menunjukkan perlunya melibatkan pegawai Dinas Kehutanan dan penyuluh sebagai peserta pelatihan dalam bidang silvikultur, sehingga mereka dapat menyebarkan informasi yang bermanfaat bagi petani dalam memperbaiki kualitas pohon kayu yang mereka pelihara.

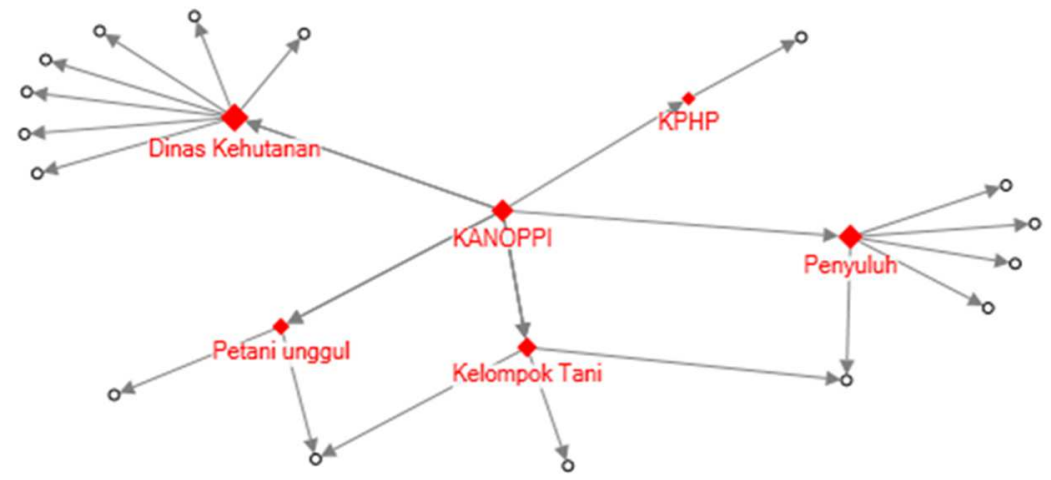

Gambar 10. Diagram jaringan sosial sumber informasi petani pada topik silvikultur

\section{III.3.2.5 Penyebaran informasi tentang topik pengelolaan kebun agroforestri}

Informasi pengelolaan kebun agroforestri yang disampaikan oleh Kanoppi adalah penanaman tanaman sela yang bernilai ekonomis di bawah naungan tanaman pohon-pohonan, contohnya adalah penanaman jahe di bawah naungan pohon jati. Informasi seperti jarak tanam yang sesuai, persentase naungan yang diperlukan, dan jenis-jenis tanaman sela yang dapat ditanam di bawah naungan disampaikan dalam pelatihan. Responden non peserta pelatihan memperoleh informasi yang disampaikan oleh Kanoppi dari Dinas Kehutanan dan penyuluh (Gambar 11). Oleh karena itu, sama halnya dengan topik silvikultur, untuk masalah budidaya perlu melibatkan Dinas Kehutanan dan penyuluh dalam menyebarkan informasi. 


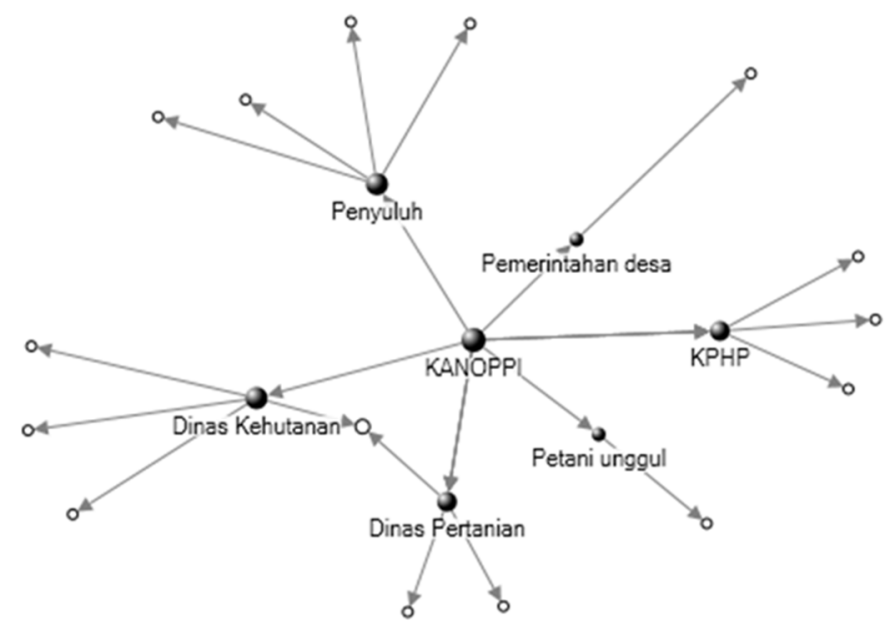

Gambar 11. Diagram jaringan sosial sumber informasi petani pada topik pengelolaan kebun agroforestri

\section{III.4 Keterkaitan antara sumber informasi, materi informasi dengan proses adopsi}

Proses adopsi pengetahuan diawali dengan berhasilnya proses penyebaran informasi kepada target (sasaran), dalam hal ini adalah petani. Setelah menerima dan memahami informasi tentang teknologi baru untuk mengatasi permasalahan yang dihadapi, petani akan melakukan uji coba. Jika teknologi baru tersebut diyakini dapat memberikan manfaat, maka mereka akan menerapkan atau mengadopsinya. Respon petani terhadap informasi mengenai teknologi baru berbeda-beda tergantung pada sumber informasi dan kesesuaian informasi yang diberikan dengan kebutuhan.

Pada studi ini diketahui bahwa pada tahapan proses adopsi untuk menilai manfaat lebih banyak dipengaruhi oleh sumber informasi yang terpercaya (Gambar 12). Begitupula untuk tahapan ujicoba yang dipengaruhi oleh sumber informasi yang terpercaya dan tipe teknologi tepat sasaran yang diperkenalkan. Sedangkan untuk tingkat adopsi, yang paling berpengaruh adalah kesederhanaan dari teknologi yang diperkenalkan. Untuk itu, selain sumber yang terpercaya, yang perlu diperhatikan dalam penyebaran informasi adalah jenis informasi yang disebarkan yang haruslah sesuai dengan kebutuhan di masyarakat. 


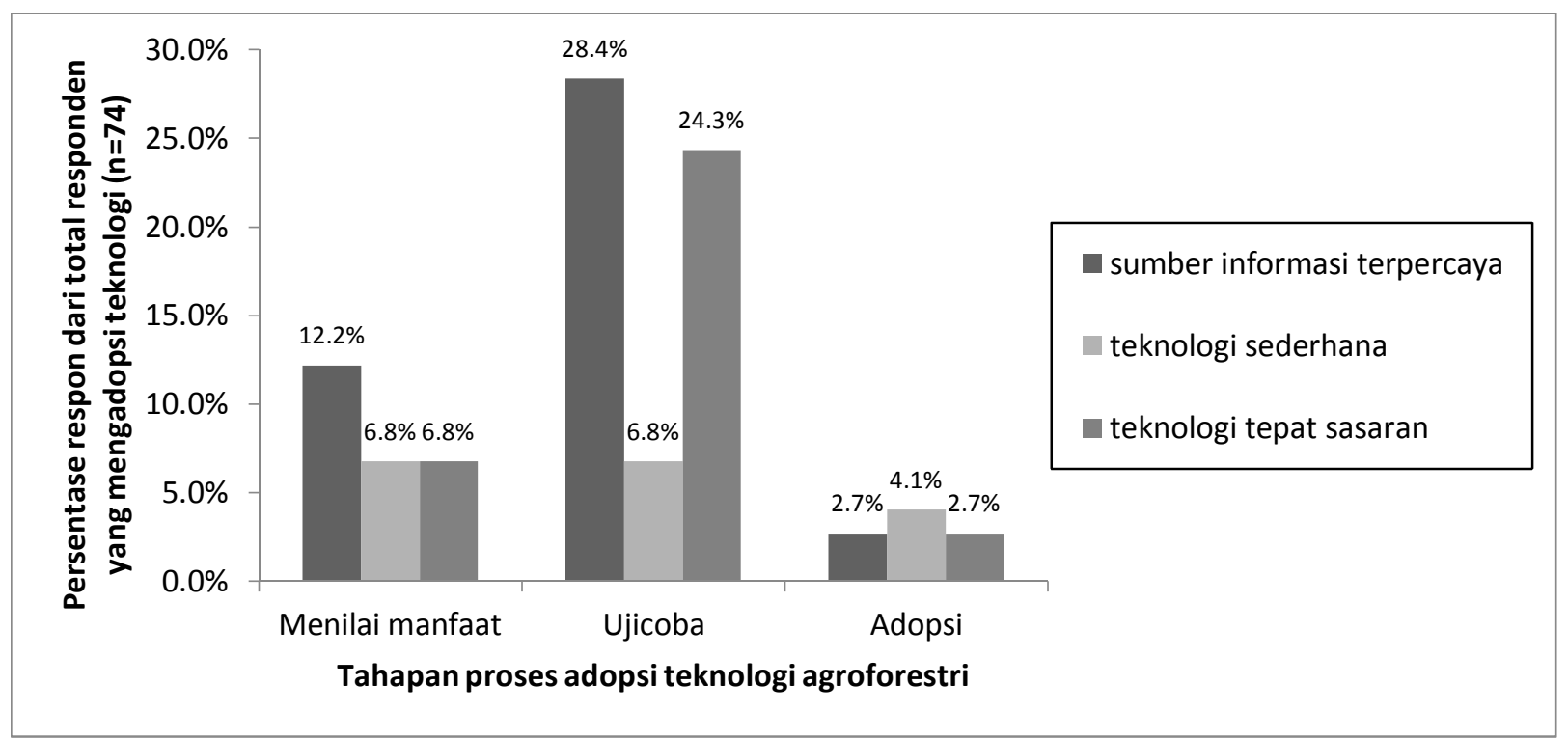

Gambar 12. Persepsi petani terhadap aspek-aspek yang mempengaruhi proses adopsi teknologi agroforestri

\section{III.5 Pengemasan pelatihan atau penyuluhan agroforestri yang sesuai kebutuhan petani}

Informasi tentang preferensi petani terhadap topik penyuluhan dan penyebaran informasi dapat digunakan sebagai dasar untuk mengemas bentuk pelatihan atau penyuluhan agroforestri agar sesuai dengan kebutuhan petani. Selain itu, evaluasi mengenai pelatihan dari para peserta juga dapat digunakan sebagai masukan dalam mengemas pelatihan atau penyuluhan sehingga pelatihan dan penyuluhan dapat memberikan dampak dan manfaat bagi peserta. Pada studi ini, evaluasi pelatihan dan penyuluhan dilakukan terhadap kriteria peserta pelatihan, metode penyuluhan yang digunakan, materi yang disampaikan, narasumber dan durasi kegiatan.

\section{III.5.1 Peserta pelatihan penyuluhan agroforestri}

Latar belakang peserta dalam pelatihan dan penyuluhan menjadi pertimbangan penting ketika melakukan pelatihan dan penyuluhan. Peserta pelatihan dan penyuluhan adalah orang yang memiliki kriteria sesuai dengan topik pelatihan dan penyuluhannya, karena diharapkan pelatihan dan penyuluhan yang diberikan dapat memberikan dampak perbaikan baik untuk peserta itu sendiri maupun orang lain yang diberi informasi oleh peserta pelatihan dan penyuluhan. Pemilihan peserta pelatihan perlu melibatkan pemangku kepentingan di lokasi sasaran dan mempertimbangkan kebutuhan dari penerima manfaat pelatihan dan penyuluhan. Berdasarkan masukan dari responden, peserta pelatihan dan penyuluhan agroforestri adalah: petani unggul atau berpengalaman, anggota kelompok tani, petani yang mempunyai motivasi dan kemauan menyebarkan pengetahuan atau petani berjiwa penyuluh, tokoh masyarakat, petani yang belum pernah mengikuti pelatihan, perempuan, petani berusia muda dan bisa baca tulis (Gambar 13). Peserta pelatihan dan penyuluhan yang merupakan anggota kelompok tani dan direkomendasikan oleh kelompoknya dapat mempermudah dalam melakukan monitoring dan evaluasi setelah selesai pelatihan, dan adanya jaminan peserta 
tersebut menyebarkan informasi yang diperoleh kepada anggota kelompok tani lainnya. Sementara, pemilihan peserta yang bukan berasal dari anggota kelompok tani dilakukan terhadap petani yang belum menerima pelatihan. Pelibatannya dalam pelatihan dimaksudkan untuk memberikan kesempatan bagi petani dalam mengakses kegiatan penyuluhan agroforestri.

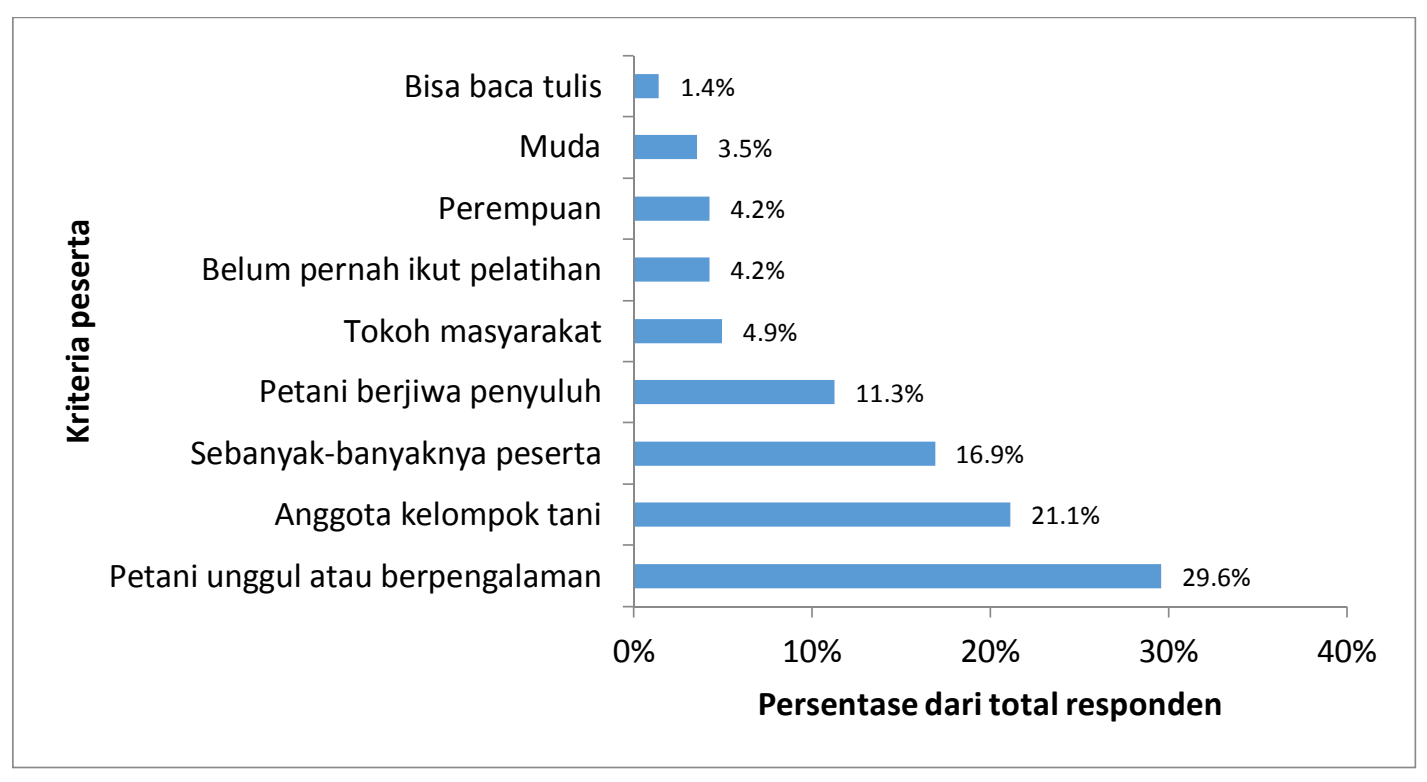

Gambar 13. Kriteria peserta pelatihan dan penyuluhan agroforestri berdasarkan masukan responden.

\section{III.5.2 Metode yang digunakan dalam penyuluhan agroforestri}

Metode penyuluhan atau pelatihan yang sudah dilakukan oleh Kanoppi adalah kombinasi antara diskusi, praktik dan kunjungan lapang, yang menurut 39\% dari peserta bawa metode tersebut sudah cukup baik. Berdasarkan masukan dari semua responden, untuk kegiatan penyuluhan ataupun pelatihan agroforestri metode yang disukai adalah kombinasi diskusi dan praktik, diikuti dengan praktik, kombinasi diskusi-praktik-kunjungan lapang (Gambar 14). Sedangkan metode yang tidak terlalu diminati oleh responden adalah diskusi saja, kombinasi praktik-kunjungan lapang, kunjungan lapang dan diskusi-kunjungan lapang. 


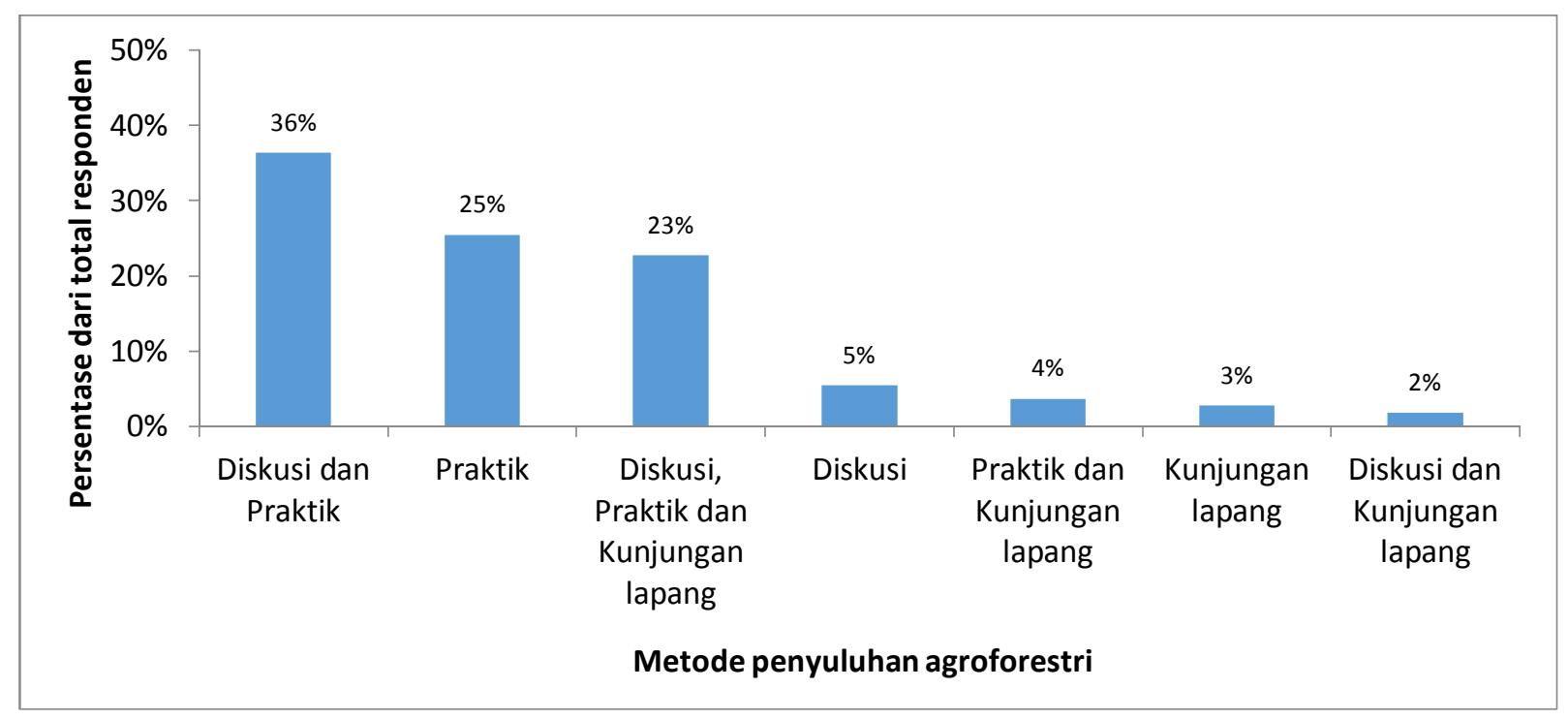

Gambar 14. Metode pelatihan atau penyuluhan agroforestri yang dipilih responden.

Berdasarkan pengalaman dari pelaksanaan pelatihan agroforestri yang dilakukan oleh Kanoppi, kombinasi metode diskusi dan praktik akan mempermudah peserta dalam mempelajari pengetahuan dan teknologi baru. Sesi diskusi dilakukan untuk menyampaikan landasan teori yang dipadukan dengan pengalaman petani sehari-hari, dan praktik untuk meningkatkan keterampilan peserta tentang teknik baru yang sedang dipelajari. Metode kunjungan lapangan dilakukan untuk membangun semangat dan wawasan peserta tentang topik yang dipelajari. Dalam kunjungan lapang, peserta diajak melihat langsung praktik-praktik yang dilakukan oleh petani atau pelaku lain yang dinilai telah berhasil, sehingga mereka termotivasi dalam menerapkan dan menyebarluaskan pengetahuan dan teknologi yang dipelajari dalam pelatihan atau penyuluhan agroforestri.

\section{III.5.3 Materi yang disampaikan dalam penyuluhan agroforestri}

Berdasarkan materi yang disampaikan dalam penyuluhan agroforestri oleh Kanoppi, sekitar $61 \%$ peserta menyatakan bahwa materi yang diberikan sudah cukup memberikan pengetahuan tentang kayu dan hasil hutan bukan kayu. Sebanyak 5\% peserta menyatakan bahwa materi pelatihan terlalu banyak dalam waktu yang singkat. Beberapa peserta menyarankan agar materi yang diberikan lebih difokuskan pada topik-topik khusus seperti pemasaran, hasil hutan bukan kayu, kebijakan terkait penatausahaan hasil hutan hak milik, silvikultur, pengelolaan agroforestri, penyuluhan, dan konservasi hutan. Responden menyarankan untuk memperdalam topik pemasaran yang meliputi: (i) informasi pasar hasil kayu dan hasil hutan bukan kayu, dan (ii) peningkatan nilai dari produk hasil hutan bukan kayu. Topik mengenai hasil hutan bukan kayu yang perlu dipelajari kembali jika ada pelatihan selanjutnya adalah: budidaya lebah sebagai penghasil madu, jahe emprit, tanaman tarum (Indigofera sp.) dan bambu.

Responden yang belum pernah mengikuti pelatihan merasa bahwa mereka memerlukan pengetahuan mengenai teknik silvikultur (pemangkasan dan penjarangan pohon), hasil hutan bukan kayu, budidaya 
tanaman sela dan tanaman buah, pemasaran produk agroforestri, pengelolaan kebun agroforestri dan konservasi hutan.

Secara umum, topik tentang teknik silvikultur dan pemasaran hasil hutan bukan kayu merupakan topik yang diperlukan dan paling banyak diminta oleh petani di ketiga kabupaten.

\section{III.5.4 Waktu dan durasi pelaksanaan penyuluhan agroforestri}

Pelatihan dan penyuluhan perlu memperhatikan waktu dan durasi agar tidak mengganggu waktuwaktu penting peserta seperti: waktu musim tanam, waktu musim panen, dan hari-hari penting agama/budaya. Waktu pelaksanaan dan durasi mempengaruhi efektifitas kegiatan penyuluhan dan jumlah peserta yang hadir. Durasi pelatihan yang dilaksanakan oleh Kanoppi selama empat hari, dianggap cukup oleh $50,9 \%$ peserta, tetapi $35 \%$ peserta menyarankan untuk menambah hari pelatihan dan sebanyak $7 \%$ peserta menyarankan mengurangi hari pelatihan.

Durasi pelatihan selama empat hari dianggap cukup, baik bagi lelaki maupun perempuan. Meskipun demikian, lelaki lebih menyukai durasi pelatihan ditambah, tetapi perempuan lebih menyukai durasi pelatihan dikurangi (Gambar 15.). Petani perempuan umumnya tidak memiliki keleluasaan waktu di luar kegiatan rumah tangga dan bertani dibanding petani lelaki. Petani perempuan memiliki keterbatasan akses untuk menghadiri pelatihan atau penyuluhan di luar desa, jika pelatihan dilaksanakan empat hari atau lebih. Beberapa responden juga menyarankan untuk mengadakan pertemuan rutin seperti sekali seminggu untuk memberikan penyuluhan tentang agroforestri kepada petani.

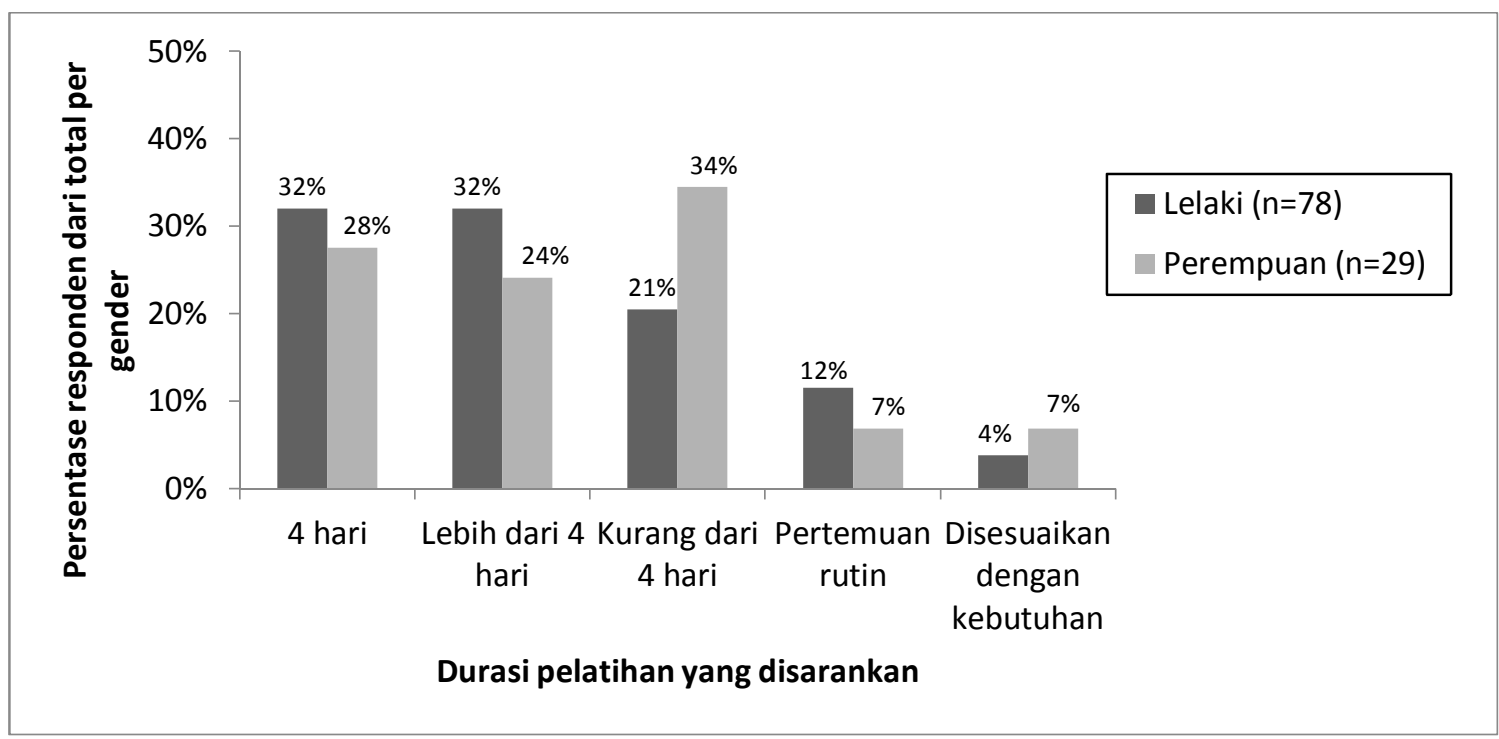

Gambar 15. Durasi hari untuk pelatihan atau penyuluhan yang disarankan baik oleh lelaki maupun perempuan 


\section{Kesimpulan dan Saran}

\section{Kesimpulan}

Petani di Kabupaten Gunungkidul, Sumbawa dan Timor Tengah Selatan petani lebih menyukai topiktopik penyuluhan yang praktis dan mendasar untuk bidang kehutanan dan agroforestri seperti: silvikultur, pengelolaan kebun agroforestri, pemasaran hasil kayu dan hasi hutan bukan kayu agar dapat mendukung kerja petani. Ketertarikan terhadap topik pelatihan tergantung pada kebiasaan yang dilakukan oleh petani pada lokasi dan gender yang berbeda.

Penyebaran informasi dari petani yang mendapat pelatihan atau penyuluhan ke petani lain yang membutuhkan informasi memiliki jalur berbeda-beda tergantung pada lokasi, gender dan sumber informasi yang ada. Secara umum, penyuluh masih memegang peran penting dalam penyebaran informasi agroforestri dan kehutanan kepada petani, selain Dinas Kehutanan dan lembaga non pemerintahan. Peran kelompok tani, keluarga, petani unggul dan lembaga non pemerintah sangat penting dalam penyebaran informasi, terutama bagi petani perempuan dalam memperoleh informasi tentang agroforestri dan kehutanan.

\section{Saran}

Pengemasan pelatihan atau penyuluhan agroforestri dan kehutanan perlu disesuaikan dengan kebutuhan petani dan kondisi lokal agar lebih memberikan manfaat. Pengemasan pelatihan atau penyuluhan agroforestri dilakukan dengan memperhatikan beberapa hal yaitu: topik, peserta pelatihan, metode, waktu dan durasi. Silvikultur, pengelolaan kebun agroforestri dan pemasaran adalah topik yang paling sering diusulkan oleh petani. Pemilihan peserta pelatihan perlu mempertimbangkan latar belakang petani, seperti: (i) anggota kelompok tani yang direkomendasikan oleh anggota kelompoknya; (ii) petani yang memiliki motivasi dan mau menyebarluaskan informasi; dan (iii) petani yang berpengalaman. Beberapa pihak dapat diikut-sertakan dalam pelatihan atau penyuluhan agroforestri dan kehutanan, antara lain: pedagang untuk topik pemasaran kayu dan non kayu, penyuluh dan petugas Dinas Kehutanan untuk topik budidaya hutan dan agroforestri, dan pemerintah desa untuk topik perijinan tata usaha penjualan dan penggunaan kayu. Metode pelatihan atau penyuluhan dapat dikemas dalam bentuk kombinasi antara diskusi, praktik, dan kunjungan lapangan untuk meningkatkan pengetahuan, keterampilan dan motivasi peserta pelatihan atau penyuluhan.

Setiap lokasi memiliki preferensi yang berbeda-beda terhadap topik penyuluhan maupun proses penyebaran informasinya. Untuk mendukung tersebarnya informasi tentang agroforestri dan kehutanan agar bermanfaat bagi petani yang membutuhkan, maka sebelum dilakukan pelatihan atau penyuluhan sebaiknya dilakukan analisa tentang aktor-aktor yang memiliki potensi penting dalam penyebaran informasi dan tingkat pengetahuan yang dimilikinya. 


\section{Daftar Pustaka}

de Foresta, A Kusworo, G Michon dan WA Djatmiko. 2000. Ketika kebun berupa hutan-Agroforest khas Indonesia - Sumbangan masyarakat bagi pembangunan berkelanjutan. International Centre for Research in Agroforestry, Bogor, Indonesia; Institut de Recherche pour le Développement, France; dan Ford Foundation, Jakarta, Indonesia.

Putro DW, Nawir AA, Rida Hakim M, Syafii S, Julmansyah, Muktasam. 2015. Laporan Penelitian Analisis Kebijakan Dalam Mendudkung Produksi, Pemasaran dan Pengolahan Hasil Hutan Kayu dan Hasil Hutan Bukan Kayu di Kabupeten Sumbawa- Nusa Tenggara Barat. Bogor - Indonesia: WWF Indonesia, Mataram Nusa Tenggara Barat.

Hairiah K, Sardjono MA dan Sabarnurdin S. 2003. Bahan Ajar 1 - Pengantar Agroforestri. World Agroforestry Centre (ICRAF) Southeast Asia Regional Office, Bogor, Indonesia.

Nair PKR. 1993. An introduction to Agroforestri. Kluwer Academic Publisher, The Netherlands.

Riyandoko, Martini E, Perdana A, Yumn A, Roshetko JM. 2016a. Existing Conditions, Challenges and Needs in the Implementation of Forestry and Agroforestry Extension in Indonesia. Working Paper no. 238. Bogor, Indonesia: World Agroforestry Centre (ICRAF) Southeast Asia Regional Program. DOI: http://dx.doi.org/10.5716/WP16141.PDF

Riyandoko, Syafii S, Abdulrahman M, Widhiana W, Junaidin, Setyawan A, Danayasa P, Sumardamto P, Joko Purwanto MT. 2016b. Panduan Pelatihan Penyuluh Swadaya dan Petani Unggul Sebagai Pendekatan Penyuluhan Agroforestri. Bogor, Indonesia: World Agroforestry Centre (ICRAF) Southeast Asia Regional Program. 
Lampiran 1. Silabus Pelatihan bagi Penyuluh Swadaya dan Petani Unggul tentang Pengembangan Produksi dan Strategi Pemasaran Kayu dan Hasil Hutan Bukan Kayu.

\begin{tabular}{|c|c|c|c|c|c|c|}
\hline No & Topik Materi & Pokok Bahasan & Tujuan & Metode & Alat \& Bahan & Waktu \\
\hline 1 & Dinamika kelompok & $\begin{array}{l}\text { - Perkenalan, mencairkan } \\
\text { suasana } \\
\text { - Identifikasi harapan } \\
\text { peserta } \\
\text { - Membangun kesepakatan } \\
\text { - Kontrak belajar }\end{array}$ & $\begin{array}{l}\text { - Saling mengenal satu sama lain } \\
\text { - Mencairkan suasana peserta } \\
\text { - Mengetahui harapan peserta } \\
\text { terhadap penyelenggaraan } \\
\text { pelatihan } \\
\text { - Menyepakati agenda dan tata } \\
\text { tertib pelatihan }\end{array}$ & $\begin{array}{l}\text { Permainan, sharing, } \\
\text { diskusi terfokus dan curah } \\
\text { pendapat }\end{array}$ & $\begin{array}{l}\text { Flipchart, spidol, } \\
\text { kertas metaplan }\end{array}$ & 60 menit \\
\hline 2 & Pretest Peserta & $\begin{array}{l}\text { Penilaian diri sendiri } \\
\text { secara cepat (rapid self } \\
\text { assessment) }\end{array}$ & $\begin{array}{l}\text { - Mengetahui kondisi awal } \\
\text { pengetahuan peserta mengenai } \\
\text { materi pelatihan }\end{array}$ & $\begin{array}{l}\text { Mengisi formulir penilaian } \\
\text { diri sendiri secara cepat } \\
\text { (rapid self assessment) } \\
\text { yang disediakan }\end{array}$ & $\begin{array}{l}\text { Formulir rapid self } \\
\text { assessment yang } \\
\text { telah di salin pada } \\
\text { kertas plano }\end{array}$ & 30 menit \\
\hline 3 & $\begin{array}{l}\text { Pengantar kayu } \\
\text { dan hasil hutan } \\
\text { bukan kayu (hhbk) } \\
\text { bagi penghidupan } \\
\text { petani dan } \\
\text { lingkungan hidup }\end{array}$ & $\begin{array}{l}\text { Pengertian hasil hutan, } \\
\text { kayu, hhbk } \\
\text { - Pengelompokan hhbk } \\
\text { (referensi Permenhut No } \\
35 \text { tahun 2007) } \\
\text { - Hasil hutan kayu dan hhbk } \\
\text { yang ada di wilayah } \\
\text { setempat }\end{array}$ & $\begin{array}{l}\text { - Peserta memahami tentang hasil } \\
\text { hutan, kayu dan hhbk. } \\
\text { - Peserta dapat mengidentifikasi } \\
\text { dan mengelompokkkan hasil } \\
\text { hutan kayu dan hhbk di } \\
\text { wilayahnya }\end{array}$ & $\begin{array}{l}\text { Presentasi, diskusi } \\
\text { terfokus, } \\
\text { Simulasi/permainan }\end{array}$ & $\begin{array}{l}\text { LCD proyektor, } \\
\text { komputer, spidol, } \\
\text { kertas metaplan, } \\
\text { papan tulis. }\end{array}$ & 60 menit \\
\hline 4 & $\begin{array}{l}\text { Kebijakan tentang } \\
\text { kayu dan hhbk }\end{array}$ & $\begin{array}{l}\text { - Kebijakan yang } \\
\text { berhubungan dengan } \\
\text { kayu. } \\
\text { - Kebijakan yang } \\
\text { berhubungan dengan } \\
\text { HHBK. }\end{array}$ & $\begin{array}{l}\text { - Peserta mengetahui dan } \\
\text { memahani tentang kebijakan yang } \\
\text { berhubungan dengan kayu dan } \\
\text { HHBK. }\end{array}$ & $\begin{array}{l}\text { Presentasi, bermain } \\
\text { peran. }\end{array}$ & $\begin{array}{l}\text { LCD proyektor, } \\
\text { komputer, spidol, } \\
\text { kertas metaplan, } \\
\text { kertas plano } \\
\text { papan tulis. }\end{array}$ & 120 menit \\
\hline 5 & $\begin{array}{l}\text { Pengantar } \\
\text { pemasaran kayu } \\
\text { dan HHBK }\end{array}$ & $\begin{array}{l}\text { - Eksplorasi pasar kayu dan } \\
\text { hhbk di wilayah. } \\
\text { - Kunjungan ke } \\
\text { pengolahan/buyer kayu } \\
\text { dan HHBK }\end{array}$ & $\begin{array}{l}\text { - Peserta dapat menilai komoditas } \\
\text { kayu dan hhbk unggulan di } \\
\text { wilayahnya. } \\
\text { - Peserta mengetahui mengetahui } \\
\text { pasar kayu dan hhbk } \\
\text { - Peserta mengetahui mata rantai } \\
\text { pemasaran kayu. }\end{array}$ & $\begin{array}{l}\text { Diskusi kelompok, } \\
\text { Kunjungan ke sawmiill } \\
\text { pengolahan kayu, } \\
\text { kunjungan ke pengolahan } \\
\text { hhbk }\end{array}$ & $\begin{array}{l}\text { Alat tulis, kertas } \\
\text { plano, spidol }\end{array}$ & 180 menit \\
\hline
\end{tabular}




\begin{tabular}{|c|c|c|c|c|c|c|}
\hline No & Topik Materi & Pokok Bahasan & Tujuan & Metode & Alat \& Bahan & Waktu \\
\hline 6 & Pengukuran Pohon & $\begin{array}{l}\text { - Pengantar tentang } \\
\text { pengukuran pohon } \\
\text { dengan berbagai metode }\end{array}$ & $\begin{array}{l}\text { - Peserta memahami tentang } \\
\text { pengukuran pohon dengan } \\
\text { beberapa metode. } \\
\text { - Peserta mengetahui peralatan } \\
\text { yang digunakan dalam } \\
\text { pengukuran. }\end{array}$ & $\begin{array}{l}\text { Presentasi, simulasi di } \\
\text { dalam kelas, curah } \\
\text { pendapat }\end{array}$ & $\begin{array}{l}\text { LCD proyektor, } \\
\text { komputer, spidol, } \\
\text { kertas metaplan, } \\
\text { papan tulis. }\end{array}$ & 120 menit \\
\hline 7 & $\begin{array}{l}\text { Praktek } \\
\text { Pengukuran pohon } \\
\text { dan perhitungan } \\
\text { volume kayu } \\
\text { secara sederhana }\end{array}$ & $\begin{array}{l}\text { - Pengukuran pohon } \\
\text { dengan beberapa metode. } \\
\text { Seperti MTG (Master } \\
\text { Tree Grower) }\end{array}$ & $\begin{array}{l}\text { - Peserta dapat melakukan } \\
\text { pengukuran pohon untuk } \\
\text { mengetahui volume kayu dengan } \\
\text { beberapa metode. }\end{array}$ & $\begin{array}{l}\text { Presentasi, } \\
\text { Praktek/latihan } \\
\text { pengukuran di demontrasi } \\
\text { plot/kebun petani yang } \\
\text { representatif, } \\
\text { Presentasi hasil dan } \\
\text { diskusi. }\end{array}$ & $\begin{array}{l}\text { Papan } \\
\text { tulis/flipcard, } \\
\text { spidol, kertas } \\
\text { Pita ukur dan alat } \\
\text { ukur kayu. }\end{array}$ & 180 menit \\
\hline 8 & $\begin{array}{l}\text { Pemeliharaan } \\
\text { pohon atau } \\
\text { silvikultur }\end{array}$ & $\begin{array}{l}\text { Penanaman, thinning, } \\
\text { pruning, dan tatacara } \\
\text { pemanenan. }\end{array}$ & $\begin{array}{l}\text { - Peserta memahani tentang } \\
\text { manajemen pemeliharaan pohon } \\
\text { (silvikultur) }\end{array}$ & $\begin{array}{l}\text { ceramah, curah } \\
\text { pendapat, } \\
\text { permainan/simulasi }\end{array}$ & $\begin{array}{l}\text { LCD proyektor, } \\
\text { komputer, spidol, } \\
\text { kertas metaplan, } \\
\text { kertas plano }\end{array}$ & 60 menit \\
\hline 9 & $\begin{array}{l}\text { Kunjungan dan } \\
\text { pengamatan } \\
\text { perlakukan } \\
\text { silviculture di kebun } \\
\text { atau demonstrasi } \\
\text { plot petani. }\end{array}$ & $\begin{array}{l}\text { - Praktik / simulasi } \\
\text { pemangkasan cabang } \\
\text { (pruning) dan penjarangan } \\
\text { pohon (thinning). } \\
\text { - Observasi Pertumbuhan } \\
\text { dan manajemen } \\
\text { pemeliharaan pohon }\end{array}$ & $\begin{array}{l}\text { Peserta memahami cara pruning } \\
\text { dan thinning di kebun jati } \\
\text { - Peserta dapat membandingkan } \\
\text { perlakukan silvikultur yang } \\
\text { dilakukan di kebun atau } \\
\text { demonstrasi plot percobaan. }\end{array}$ & $\begin{array}{l}\text { Praktek/simulasi, } \\
\text { Observasi, presentasi, } \\
\text { dikusi terfokus }\end{array}$ & $\begin{array}{l}\text { Papan } \\
\text { tulis/flipcard, } \\
\text { spidol, kertas } \\
\text { metaplan, kertas } \\
\text { plano, solatip } \\
\text { kertas, kertas hvs. }\end{array}$ & 180 menit \\
\hline 10 & $\begin{array}{l}\text { Pengelolaan kebun } \\
\text { dari berbagai tipe } \\
\text { integrasi kayu dan } \\
\text { hhbk. }\end{array}$ & $\begin{array}{l}\text { - Alternatif pengelolaan } \\
\text { kebun integrasi kayu dan } \\
\text { hhbk } \\
\text { - Wanatani/ kebun campur } \\
\text { pertanian } \\
\text { - Wanaternak } \\
\text { - Agrosilvofishery/kebun } \\
\text { campur perikanan }\end{array}$ & $\begin{array}{l}\text { - Peserta mengetahui beberapa } \\
\text { bentuk pengeloaan kebun } \\
\text { campuran integrasi kayu dan } \\
\text { hhbk. }\end{array}$ & $\begin{array}{l}\text { Presentasi, sharing, } \\
\text { diskusi terfokus dan curah } \\
\text { pendapat. }\end{array}$ & $\begin{array}{l}\text { LCD proyektor, } \\
\text { komputer, spidol, } \\
\text { kertas metaplan, } \\
\text { kertas plano, } \\
\text { solatip kertas, } \\
\text { kertas hvs, papan } \\
\text { tulis, }\end{array}$ & 60 menit \\
\hline 11 & $\begin{array}{l}\text { Studi kasus di plot } \\
\text { demonstrasi } \\
\text { percobaan integrasi }\end{array}$ & $\begin{array}{l}\text { - Penyampaian salah satu } \\
\text { konsep integrasi kayu dan } \\
\text { hhbk dengan konsep } \\
\text { kebun campur. }\end{array}$ & $\begin{array}{l}\text { Petani mengetahui salah satu } \\
\text { pilihan pengelolaan kebun yang } \\
\text { terintegrasi antara kayu dan hhbk. }\end{array}$ & $\begin{array}{l}\text { Presentasi, sharing, curah } \\
\text { pendapat }\end{array}$ & $\begin{array}{l}\text { LCD proyektor, } \\
\text { komputer, spidol, } \\
\text { kertas metaplan, } \\
\text { kertas plano, }\end{array}$ & 60 menit \\
\hline
\end{tabular}




\begin{tabular}{|c|c|c|c|c|c|c|}
\hline No & Topik Materi & Pokok Bahasan & Tujuan & Metode & Alat \& Bahan & Waktu \\
\hline & $\begin{array}{l}\text { jati dengan jahe } \\
\text { emprit dan kencur }\end{array}$ & $\begin{array}{l}\text { - Konsep integrasi jati dan } \\
\text { jahe emprit. }\end{array}$ & & & $\begin{array}{l}\text { solatip kertas, } \\
\text { kertas hvs, papan } \\
\text { tulis }\end{array}$ & \\
\hline 12 & $\begin{array}{l}\text { Kunjungan dan } \\
\text { Pengamatan } \\
\text { pertumbuhan jahe } \\
\text { emprit dan kencur } \\
\text { di bawah tegakan } \\
\text { jati dengan } \\
\text { perlakuan } \\
\text { pemangkasan } \\
\text { cabang dan } \\
\text { penjarangan pohon }\end{array}$ & $\begin{array}{l}\text { - Observasi pertumbuhan } \\
\text { jahe emprit dan kencur di } \\
\text { bawah tegakan jati } \\
\text { - Manfaat dan pengelolaan } \\
\text { kebun campuran di } \\
\text { demontrasi plot } \\
\text { percobaan. }\end{array}$ & $\begin{array}{l}\text { - Peserta memahami pengelolaan } \\
\text { kebun yang integrasi antara kayu } \\
\text { dan hhbk. } \\
\text { - Peserta mengetahui perbedaan } \\
\text { pertumbuhan jahe emprit dan } \\
\text { kencur di masing-masing } \\
\text { perlakuan pemangkasan cabang } \\
\text { dan penjarangan pohon tanaman } \\
\text { jati. }\end{array}$ & $\begin{array}{l}\text { Observasi, diskusi } \\
\text { kelompok, presentasi }\end{array}$ & $\begin{array}{l}\text { Alat tulis, kertas } \\
\text { plano }\end{array}$ & 180 menit \\
\hline 13 & $\begin{array}{l}\text { RTL (Rencana } \\
\text { Tindak Lanjut) \& } \\
\text { evaluasi kegiatan } \\
\text { Postest }\end{array}$ & $\begin{array}{l}\text { - RTL \& Evaluasi kegiatan } \\
\text { - Post test peserta }\end{array}$ & $\begin{array}{l}\text { - Menyusun rencana tindak lanjut } \\
\text { peserta setelah pelatihan. } \\
\text { - Mengetahui kondisi peserta } \\
\text { setelah pelatihan }\end{array}$ & $\begin{array}{l}\text { Diskusi terfokus. } \\
\text { Rapid self assesment }\end{array}$ & $\begin{array}{l}\text { Kertas Plano } \\
\text { Formulir rapid self } \\
\text { assessment }\end{array}$ & 60 menit \\
\hline
\end{tabular}




\section{WORKING PAPERS WITH DOIS}

2005

1. Agroforestry in the drylands of eastern Africa: a call to action

2. Biodiversity conservation through agroforestry: managing tree species diversity within a network of community-based, nongovernmental, governmental and research organizations in western Kenya.

3. Invasion of prosopis juliflora and local livelihoods: Case study from the Lake Baringo area of Kenya

4. Leadership for change in farmers organizations: Training report: Ridar Hotel, Kampala, 29th March to 2nd April 2005.

5. Domestication des espèces agroforestières au Sahel : situation actuelle et perspectives

6. Relevé des données de biodiversité ligneuse: Manuel du projet biodiversité des parcs agroforestiers au Sahel

7. Improved land management in the Lake Victoria Basin: TransVic Project's draft report.

8. Livelihood capital, strategies and outcomes in the Taita hills of Kenya

9. Les espèces ligneuses et leurs usages: Les préférences des paysans dans le Cercle de Ségou, au Mali

10. La biodiversité des espèces ligneuses: Diversité arborée et unités de gestion du terroir dans le Cercle de Ségou, au Mali

\section{6}

11. Bird diversity and land use on the slopes of Mt. Kilimanjaro and the adjacent plains, Tanzania

12. Water, women and local social organization in the Western Kenya Highlands

13. Highlights of ongoing research of the World Agroforestry Centre in Indonesia

14. Prospects of adoption of tree-based systems in a rural landscape and its likely impacts on carbon stocks and farmers' welfare: The FALLOW Model Application in Muara Sungkai, Lampung, Sumatra, in a 'Clean Development Mechanism' context

15. Equipping integrated natural resource managers for healthy Agroforestry landscapes.

17. Agro-biodiversity and CGIAR tree and forest science: approaches and examples from Sumatra.

18. Improving land management in eastern and southern Africa: A review of policies.

19. Farm and household economic study of Kecamatan Nanggung, Kabupaten Bogor, Indonesia: A socio-economic base line study of Agroforestry innovations and livelihood enhancement.

20. Lessons from eastern Africa's unsustainable charcoal business.

21. Evolution of RELMA's approaches to land management: Lessons from two decades of research and development in eastern and southern Africa

22. Participatory watershed management: Lessons from RELMA's work with farmers in eastern Africa.

23. Strengthening farmers' organizations: The experience of RELMA and ULAMP.

24. Promoting rainwater harvesting in eastern and southern Africa.

25. The role of livestock in integrated land management.

26. Status of carbon sequestration projects in Africa: Potential benefits and challenges to scaling up. 
27. Social and Environmental Trade-Offs in Tree Species Selection: A Methodology for Identifying Niche Incompatibilities in Agroforestry [Appears as AHI Working Paper no. 9]

28. Managing tradeoffs in agroforestry: From conflict to collaboration in natural resource management. [Appears as AHI Working Paper no. 10]

29. Essai d'analyse de la prise en compte des systemes agroforestiers pa les legislations forestieres au Sahel: Cas du Burkina Faso, du Mali, du Niger et du Senegal.

30. Etat de la recherche agroforestière au Rwanda etude bibliographique, période 1987-2003

2007

31. Science and technological innovations for improving soil fertility and management in Africa: A report for NEPAD's Science and Technology Forum.

32. Compensation and rewards for environmental services.

33. Latin American regional workshop report compensation.

34. Asia regional workshop on compensation ecosystem services.

35. Report of African regional workshop on compensation ecosystem services.

36. Exploring the inter-linkages among and between compensation and rewards for ecosystem services CRES and human well-being

37. Criteria and indicators for environmental service compensation and reward mechanisms: realistic, voluntary, conditional and pro-poor

38. The conditions for effective mechanisms of compensation and rewards for environmental services.

39. Organization and governance for fostering Pro-Poor Compensation for Environmental Services.

40. How important are different types of compensation and reward mechanisms shaping poverty and ecosystem services across Africa, Asia \& Latin America over the Next two decades?

41. Risk mitigation in contract farming: The case of poultry, cotton, woodfuel and cereals in East Africa.

42. The RELMA savings and credit experiences: Sowing the seed of sustainability

43. Yatich J., Policy and institutional context for NRM in Kenya: Challenges and opportunities for Landcare.

44. Nina-Nina Adoung Nasional di So! Field test of rapid land tenure assessment (RATA) in the Batang Toru Watershed, North Sumatera.

45. Is Hutan Tanaman Rakyat a new paradigm in community based tree planting in Indonesia?

46. Socio-Economic aspects of brackish water aquaculture (Tambak) production in Nanggroe Aceh Darrusalam.

47. Farmer livelihoods in the humid forest and moist savannah zones of Cameroon.

48. Domestication, genre et vulnérabilité : Participation des femmes, des Jeunes et des catégories les plus pauvres à la domestication des arbres agroforestiers au Cameroun.

49. Land tenure and management in the districts around Mt Elgon: An assessment presented to the Mt Elgon ecosystem conservation programme.

50. The production and marketing of leaf meal from fodder shrubs in Tanga, Tanzania: A pro-poor enterprise for improving livestock productivity.

51. Buyers Perspective on Environmental Services (ES) and Commoditization as an approach to liberate ES markets in the Philippines. 
52. Towards Towards community-driven conservation in southwest China: Reconciling state and local perceptions.

53. Biofuels in China: An Analysis of the Opportunities and Challenges of Jatropha curcas in Southwest China.

54. Jatropha curcas biodiesel production in Kenya: Economics and potential value chain development for smallholder farmers

55. Livelihoods and Forest Resources in Aceh and Nias for a Sustainable Forest Resource Management and Economic Progress

56. Agroforestry on the interface of Orangutan Conservation and Sustainable Livelihoods in Batang Toru, North Sumatra.

2008

57. Assessing Hydrological Situation of Kapuas Hulu Basin, Kapuas Hulu Regency, West Kalimantan.

58. Assessing the Hydrological Situation of Talau Watershed, Belu Regency, East Nusa Tenggara.

59. Kajian Kondisi Hidrologis DAS Talau, Kabupaten Belu, Nusa Tenggara Timur.

60. Kajian Kondisi Hidrologis DAS Kapuas Hulu, Kabupaten Kapuas Hulu, Kalimantan Barat.

61. Lessons learned from community capacity building activities to support agroforest as sustainable economic alternatives in Batang Toru orang utan habitat conservation program (Martini, Endri et al.)

62. Mainstreaming Climate Change in the Philippines.

63. A Conjoint Analysis of Farmer Preferences for Community Forestry Contracts in the Sumber Jaya Watershed, Indonesia.

64. The highlands: a shared water tower in a changing climate and changing Asia

65. Eco-Certification: Can It Deliver Conservation and Development in the Tropics.

66. Designing ecological and biodiversity sampling strategies. Towards mainstreaming climate change in grassland management.

67. Towards mainstreaming climate change in grassland management policies and practices on the Tibetan Plateau

68. An Assessment of the Potential for Carbon Finance in Rangelands

69 ECA Trade-offs Among Ecosystem Services in the Lake Victoria Basin.

69. The last remnants of mega biodiversity in West Java and Banten: an in-depth exploration of RaTA (Rapid Land Tenure Assessment) in Mount Halimun-Salak National Park Indonesia

70. Le business plan d'une petite entreprise rurale de production et de commercialisation des plants des arbres locaux. Cas de quatre pépinières rurales au Cameroun.

71. Les unités de transformation des produits forestiers non ligneux alimentaires au Cameroun. Diagnostic technique et stratégie de développement Honoré Tabuna et Ingratia Kayitavu.

72. Les exportateurs camerounais de safou (Dacryodes edulis) sur le marché sous régional et international. Profil, fonctionnement et stratégies de développement.

73. Impact of the Southeast Asian Network for Agroforestry Education (SEANAFE) on agroforestry education capacity.

74. Setting landscape conservation targets and promoting them through compatible land use in the Philippines.

75. Review of methods for researching multistrata systems. 
76. Study on economical viability of Jatropha curcas L. plantations in Northern Tanzania assessing farmers' prospects via cost-benefit analysis

77. Cooperation in Agroforestry between Ministry of Forestry of Indonesia and International Center for Research in Agroforestry

78. "China's bioenergy future. an analysis through the Lens if Yunnan Province

79. Land tenure and agricultural productivity in Africa: A comparative analysis of the economics literature and recent policy strategies and reforms

80. Boundary organizations, objects and agents: linking knowledge with action in Agroforestry watersheds

81. Reducing emissions from deforestation and forest degradation (REDD) in Indonesia: options and challenges for fair and efficient payment distribution mechanisms

2009

82. Mainstreaming climate change into agricultural education: challenges and perspectives

83. Challenging conventional mindsets and disconnects in conservation: the emerging role of ecoagriculture in Kenya's landscape mosaics

84. Lesson learned RATA garut dan bengkunat: suatu upaya membedah kebijakan pelepasan kawasan hutan dan redistribusi tanah bekas kawasan hutan

85. The emergence of forest land redistribution in Indonesia

86. Commercial opportunities for fruit in Malawi

87. Status of fruit production processing and marketing in Malawi

88. Fraud in tree science

89. Trees on farm: analysis of global extent and geographical patterns of agroforestry

90. The springs of Nyando: water, social organization and livelihoods in Western Kenya

91. Building capacity toward region-wide curriculum and teaching materials development in agroforestry education in Southeast Asia

92. Overview of biomass energy technology in rural Yunnan (Chinese - English abstract)

93. A pro-growth pathway for reducing net GHG emissions in China

94. Analysis of local livelihoods from past to present in the central Kalimantan Ex-Mega Rice Project area

95. Constraints and options to enhancing production of high quality feeds in dairy production in Kenya, Uganda and Rwanda

2010

96. Agroforestry education in the Philippines: status report from the Southeast Asian Network for Agroforestry Education (SEANAFE)

97. Economic viability of Jatropha curcas L. plantations in Northern Tanzania- assessing farmers' prospects via cost-benefit analysis.

98. Hot spot of emission and confusion: land tenure insecurity, contested policies and competing claims in the central Kalimantan Ex-Mega Rice Project area

99. Agroforestry competences and human resources needs in the Philippines

100. CES/COS/CIS paradigms for compensation and rewards to enhance environmental Services 
101. Case study approach to region-wide curriculum and teaching materials development in agroforestry education in Southeast Asia

102. Stewardship agreement to reduce emissions from deforestation and degradation (REDD): Lubuk Beringin's Hutan Desa as the first village forest in Indonesia

103. Landscape dynamics over time and space from ecological perspective

104. Komoditisasi atau koinvestasi jasa lingkungan: skema imbal jasa lingkungan program peduli sungai di DAS Way Besai, Lampung, Indonesia

105. Improving smallholders' rubber quality in Lubuk Beringin, Bungo district, Jambi province, Indonesia: an initial analysis of the financial and social benefits

106. Rapid Carbon Stock Appraisal (RACSA) in Kalahan, Nueva Vizcaya, Philippines

107. Tree domestication by ICRAF and partners in the Peruvian Amazon: lessons learned and future prospects in the domain of the Amazon Initiative eco-regional program

108. Memorias del Taller Nacional: "Iniciativas para Reducir la Deforestación en la region Andino Amazónica", 09 de Abril del 2010. Proyecto REALU Peru

109. Percepciones sobre la Equidad y Eficiencia en la cadena de valor de REDD en Perú -Reporte de Talleres en Ucayali, San Martín y Loreto, 2009. Proyecto REALU-Perú.

110. Reducción de emisiones de todos los Usos del Suelo. Reporte del Proyecto REALU Perú Fase 1

111. Programa Alternativas a la Tumba-y-Quema (ASB) en el Perú. Informe Resumen y Síntesis de la Fase II. 2da. versión revisada

112. Estudio de las cadenas de abastecimiento de germoplasma forestal en la amazonía Boliviana

113. Biodiesel in the Amazon

114. Estudio de mercado de semillas forestales en la amazonía Colombiana

115. Estudio de las cadenas de abastecimiento de germoplasma forestal en Ecuador http://dx.doi.org10.5716/WP10340.PDF

116. How can systems thinking, social capital and social network analysis help programs achieve impact at scale?

117. Energy policies, forests and local communities in the Ucayali Region, Peruvian Amazon

118. NTFPs as a Source of Livelihood Diversification for Local Communities in the Batang Toru Orangutan Conservation Program

119. Studi Biodiversitas: Apakah agroforestry mampu mengkonservasi keanekaragaman hayati di DAS Konto?

120. Estimasi Karbon Tersimpan di Lahan-lahan Pertanian di DAS Konto, Jawa Timur

121. Implementasi Kaji Cepat Hidrologi (RHA) di Hulu DAS Brantas, Jawa Timur. http://dx.doi.org/10.5716/WP10338.PDF

122. Kaji Cepat Hidrologi di Daerah Aliran Sungai Krueng Peusangan, NAD,Sumatra http://dx.doi.org/10.5716/WP10337.PDF

123. A Study of Rapid Hydrological Appraisal in the Krueng Peusangan Watershed, NAD, Sumatra. http://dx.doi.org/10.5716/WP10339.PDF

2011

124. An Assessment of farm timber value chains in Mt Kenya area, Kenya

125. A Comparative financial analysis of current land use systems and implications for the adoption of improved agroforestry in the East Usambaras, Tanzania

126. Agricultural monitoring and evaluation systems 
127. Challenges and opportunities for collaborative landscape governance in the East Usambara Mountains, Tanzania

128. Transforming Knowledge to Enhance Integrated Natural Resource Management Research, Development and Advocacy in the Highlands of Eastern Africa http://dx.doi.org/10.5716/WP11084.PDF

129. Carbon-forestry projects in the Philippines: potential and challenges The Mt Kitanglad Range forest-carbon development http://dx.doi.org10.5716/WP11054.PDF

130. Carbon forestry projects in the Philippines: potential and challenges. The Arakan Forest Corridor forest-carbon project. http://dx.doi.org10.5716/WP11055.PDF

131. Carbon-forestry projects in the Philippines: potential and challenges. The Laguna Lake Development Authority's forest-carbon development project. http://dx.doi.org/10.5716/WP11056.PDF

132. Carbon-forestry projects in the Philippines: potential and challenges. The Quirino forest-carbon development project in Sierra Madre Biodiversity Corridor http://dx.doi.org10.5716/WP11057.PDF

133. Carbon-forestry projects in the Philippines: potential and challenges. The Ikalahan Ancestral Domain forest-carbon development http://dx.doi.org10.5716/WP11058.PDF

134. The Importance of Local Traditional Institutions in the Management of Natural Resources in the Highlands of Eastern Africa. http://dx.doi.org/10.5716/WP11085.PDF

135. Socio-economic assessment of irrigation pilot projects in Rwanda. http://dx.doi.org/10.5716/WP11086.PDF

136. Performance of three rambutan varieties (Nephelium lappaceum L.) on various nursery media. http://dx.doi.org/10.5716/WP11232.PDF

137. Climate change adaptation and social protection in agroforestry systems: enhancing adaptive capacity and minimizing risk of drought in Zambia and Honduras http://dx.doi.org/10.5716/WP11269.PDF

138. Does value chain development contribute to rural poverty reduction? Evidence of asset building by smallholder coffee producers in Nicaragua http://dx.doi.org/10.5716/WP11271.PDF

139. Potential for biofuel feedstock in Kenya. http://dx.doi.org/10.5716/WP11272.PDF

140. Impact of fertilizer trees on maize production and food security in six districts of Malawi. http://dx.doi.org/10.5716/WP11281.PDF

2012

141. Fortalecimiento de capacidades para la gestión del Santuario Nacional Pampa Hermosa: Construyendo las bases para un manejo adaptativo para el desarrollo local. Memorias del Proyecto. http://dx.doi.org/10.5716/WP12005.PDF

142. Understanding rural institutional strengthening: A cross-level policy and institutional framework for sustainable development in Kenya http://dx.doi.org/10.5716/WP12012.PDF

143. Climate change vulnerability of agroforestry http://dx.doi.org/10.5716/WP16722.PDF

144. Rapid assesment of the inner Niger delta of Mali http://dx.doi.org/10.5716/WP12021.PDF

145. Designing an incentive program to reduce on-farm deforestationin the East Usambara Mountains, Tanzania http://dx.doi.org/10.5716/WP12048.PDF

146. Extent of adoption of conservation agriculture and agroforestry in Africa: the case of Tanzania, Kenya, Ghana, and Zambia http://dx.doi.org/10.5716/WP12049.PDF 
147. Policy incentives for scaling up conservation agriculture with trees in Africa: the case of Tanzania, Kenya, Ghana and Zambia http://dx.doi.org/10.5716/WP12050.PDF

148. Commoditized or co-invested environmental services? Rewards for environmental services scheme: River Care program Way Besai watershed, Lampung, Indonesia.

http://dx.doi.org/10.5716/WP12051.PDF

149. Assessment of the headwaters of the Blue Nile in Ethiopia. http://dx.doi.org/10.5716/WP12160.PDF

150. Assessment of the uThukela Watershed, Kwazaulu. http://dx.doi.org/10.5716/WP12161.PDF

151. Assessment of the Oum Zessar Watershed of Tunisia. http://dx.doi.org/10.5716/WP12162.PDF

152. Assessment of the Ruwenzori Mountains in Uganda. http://dx.doi.org/10.5716/WP12163.PDF

153. History of agroforestry research and development in Viet Nam. Analysis of research opportunities and gaps. http://dx.doi.org/10.5716/WP12052.PDF

154. REDD+ in Indonesia: a Historical Perspective. http://dx.doi.org/10.5716/WP12053.PDF

155. Agroforestry and Forestry in Sulawesi series: Livelihood strategies and land use system dynamics in South Sulawesi http://dx.doi.org/10.5716/WP12054.PDF

156. Agroforestry and Forestry in Sulawesi series: Livelihood strategies and land use system dynamics in Southeast Sulawesi. http://dx.doi.org/10.5716/WP12055.PDF

157. Agroforestry and Forestry in Sulawesi series: Profitability and land-use systems in South and Southeast Sulawesi. http://dx.doi.org/10.5716/WP12056.PDF

158. Agroforestry and Forestry in Sulawesi series: Gender, livelihoods and land in South and Southeast Sulawesi http://dx.doi.org/10.5716/WP12057.PDF

159. Agroforestry and Forestry in Sulawesi series: Agroforestry extension needs at the community level in AgFor project sites in South and Southeast Sulawesi, Indonesia. http://dx.doi.org/10.5716/WP12058.PDF

160. Agroforestry and Forestry in Sulawesi series: Rapid market appraisal of agricultural, plantation and forestry commodities in South and Southeast Sulawesi.

http://dx.doi.org/10.5716/WP12059.PDF

2013

161. Diagnosis of farming systems in the Agroforestry for Livelihoods of Smallholder farmers in Northwestern Viet Nam project http://dx.doi.org/10.5716/WP13033.PDF

162. Ecosystem vulnerability to climate change: a literature review. http://dx.doi.org/10.5716/WP13034.PDF

163. Local capacity for implementing payments for environmental services schemes: lessons from the RUPES project in northeastern Viet Nam http://dx.doi.org/10.5716/WP13046.PDF

164. Seri Agroforestri dan Kehutanan di Sulawesi: Agroforestry dan Kehutanan di Sulawesi: Strategi mata pencaharian dan dinamika sistem penggunaan lahan di Sulawesi Selatan http://dx.doi.org/10.5716/WP13040.PDF

165. Seri Agroforestri dan Kehutanan di Sulawesi: Mata pencaharian dan dinamika sistem penggunaan lahan di Sulawesi Tenggara http://dx.doi.org/10.5716/WP13041.PDF

166. Seri Agroforestri dan Kehutanan di Sulawesi: Profitabilitas sistem penggunaan lahan di Sulawesi Selatan dan Sulawesi Tenggara http://dx.doi.org/10.5716/WP13042.PDF

167. Seri Agroforestri dan Kehutanan di Sulawesi: Gender, mata pencarian dan lahan di Sulawesi Selatan dan Sulawesi Tenggara http://dx.doi.org/10.5716/WP13043.PDF 
168. Seri Agroforestri dan Kehutanan di Sulawesi: Kebutuhan penyuluhan agroforestri pada tingkat masyarakat di lokasi proyek AgFor di Sulawesi Selatan dan Tenggara, Indonesia. http://dx.doi.org/10.5716/WP13044.PDF

169. Seri Agroforestri dan Kehutanan di Sulawesi: Laporan hasil penilaian cepat untuk komoditas pertanian, perkebunan dan kehutanan di Sulawesi Selatan dan Tenggara http://dx.doi.org/10.5716/WP13045.PDF

170. Agroforestry, food and nutritional security http://dx.doi.org/10.5716/WP13054.PDF

171. Stakeholder Preferences over Rewards for Ecosystem Services: Implications for a REDD+ Benefit Distribution System in Viet Nam http://dx.doi.org/10.5716/WP13057.PDF

172. Payments for ecosystem services schemes: project-level insights on benefits for ecosystems and the rural poor http://dx.doi.org/10.5716/WP13001.PDF

173. Good practices for smallholder teak plantations: keys to success http://dx.doi.org/10.5716/WP13246.PDF

174. Market analysis of selected agroforestry products in the Vision for Change Project intervention Zone, Côte d'Ivoire http://dx.doi.org/10.5716/WP13249.PDF

175. Rattan futures in Katingan: why do smallholders abandon or keep their gardens in Indonesia's 'rattan district'? http://dx.doi.org/10.5716/WP13251.PDF

176. Management along a gradient: the case of Southeast Sulawesi's cacao production landscapes http://dx.doi.org/10.5716/WP13265.PDF

2014

177. Are trees buffering ecosystems and livelihoods in agricultural landscapes of the Lower Mekong Basin? Consequences for climate-change adaptation. http://dx.doi.org/10.5716/WP14047.PDF

178. Agroforestry, livestock, fodder production and climate change adaptation and mitigation in East Africa: issues and options. http://dx.doi.org/10.5716/WP14050.PDF

179. Trees on farms: an update and reanalysis of agroforestry's global extent and socio-ecological characteristics. http://dx.doi.org/10.5716/WP14064.PDF

180. Beyond reforestation: an assessment of Vietnam's REDD+ readiness. http://dx.doi.org/10.5716/WP14097.PDF

181. Farmer-to-farmer extension in Kenya: the perspectives of organizations using the approach. http://dx.doi.org/10.5716/WP14380.PDF

182. Farmer-to-farmer extension in Cameroon: a survey of extension organizations. http://dx.doi.org/10.5716/WP14383.PDF

183. Farmer-to-farmer extension approach in Malawi: a survey of organizations: a survey of organizations http://dx.doi.org/10.5716/WP14391.PDF

184. Seri Agroforestri dan Kehutanan di Sulawesi: Kuantifikasi jasa lingkungan air dan karbon pola agroforestri pada hutan rakyat di wilayah sungai Jeneberang

185. Options for Climate-Smart Agriculture at Kaptumo Site in Kenyahttp://dx.doi.org/10.5716/WP14394.PDF

2015

186. Agroforestry for Landscape Restoration and Livelihood Development in Central Asia http://dx.doi.org/10.5716/WP14143.PDF 
187. "Projected Climate Change and Impact on Bioclimatic Conditions in the Central and SouthCentral Asia Region" http://dx.doi.org/10.5716/WP14144.PDF

188. Land Cover Changes, Forest Loss and Degradation in Kutai Barat, Indonesia. http://dx.doi.org/10.5716/WP14145.PDF

189. The Farmer-to-Farmer Extension Approach in Malawi: A Survey of Lead Farmers. http://dx.doi.org/10.5716/WP14152.PDF

190. Evaluating indicators of land degradation and targeting agroforestry interventions in smallholder farming systems in Ethiopia. http://dx.doi.org/10.5716/WP14252.PDF

191. Land health surveillance for identifying land constraints and targeting land management options in smallholder farming systems in Western Cameroon

192. Land health surveillance in four agroecologies in Malawi

193. Cocoa Land Health Surveillance: an evidence-based approach to sustainable management of cocoa landscapes in the Nawa region, South-West Côte d'Ivoire http://dx.doi.org/10.5716/WP14255.PDF

194. Situational analysis report: Xishuangbanna autonomous Dai Prefecture, Yunnan Province, China. http://dx.doi.org/10.5716/WP14255.PDF

195. Farmer-to-farmer extension: a survey of lead farmers in Cameroon. http://dx.doi.org/10.5716/WP15009.PDF

196. From transition fuel to viable energy source Improving sustainability in the sub-Saharan charcoal sector http://dx.doi.org/10.5716/WP15011.PDF

197. Mobilizing Hybrid Knowledge for More Effective Water Governance in the Asian Highlands http://dx.doi.org/10.5716/WP15012.PDF

198. Water Governance in the Asian Highlands http://dx.doi.org/10.5716/WP15013.PDF

199. Assessing the Effectiveness of the Volunteer Farmer Trainer Approach in Dissemination of Livestock Feed Technologies in Kenya vis-à-vis other Information Sources http://dx.doi.org/10.5716/WP15022.PDF

200. The rooted pedon in a dynamic multifunctional landscape: Soil science at the World Agroforestry Centre http://dx.doi.org/10.5716/WP15023.PDF

201. Characterising agro-ecological zones with local knowledge. Case study: Huong Khe district, $\mathrm{Ha}$ Tinh, Viet Nam http://dx.doi.org/10.5716/WP15050.PDF

202. Looking back to look ahead: Insight into the effectiveness and efficiency of selected advisory approaches in the dissemination of agricultural technologies indicative of Conservation Agriculture with Trees in Machakos County, Kenya. http://dx.doi.org/10.5716/WP15065.PDF

203. Pro-poor Biocarbon Projects in Eastern Africa Economic and Institutional Lessons. http://dx.doi.org/10.5716/WP15022.PDF

204. Projected climate change impacts on climatic suitability and geographical distribution of banana and coffee plantations in Nepal. http://dx.doi.org/10.5716/WP15294.PDF

205. Agroforestry and Forestry in Sulawesi series: Smallholders' coffee production and marketing in Indonesia. A case study of two villages in South Sulawesi Province. http://dx.doi.org/10.5716/WP15690.PDF

206. Mobile phone ownership and use of short message service by farmer trainers: a case study of Olkalou and Kaptumo in Kenya http://dx.doi.org/10.5716/WP15691.PDF

207. Associating multivariate climatic descriptors with cereal yields: a case study of Southern Burkina Faso http://dx.doi.org/10.5716/WP15273.PDF

208. Preferences and adoption of livestock feed practices among farmers in dairy management groups in Kenya http://dx.doi.org/10.5716/WP15675.PDF 
209. Scaling up climate-smart agriculture: lessons learned from South Asia and pathways for success http://dx.doi.org/10.5716/WP15720.PDF

210. Agroforestry and Forestry in Sulawesi series: Local perceptions of forest ecosystem services and collaborative formulation of reward mechanisms in South and Southeast Sulawesi http://dx.doi.org/10.5716/WP15721.PDF

211. Potential and challenges in implementing the co-investment of ecosystem services scheme in Buol District, Indonesia. http://dx.doi.org/10.5716/WP15722.PDF

212. Tree diversity and its utilization by the local community in Buol District, Indonesia http://dx.doi.org/10.5716/WP15723.PDF

213 Vulnerability of smallholder farmers and their preferences on farming practices in Buol District, Indonesia http://dx.doi.org/10.5716/WP15724.PDF

214. Dynamics of Land Use/Cover Change and Carbon Emission in Buol District, Indonesia http://dx.doi.org/10.5716/WP15725.PDF

215. Gender perspective in smallholder farming practices in Lantapan, Phillippines. http://dx.doi.org/10.5716/WP15726.PDF

216. Vulnerability of smallholder farmers in Lantapan, Bukidnon. http://dx.doi.org/10.5716/WP15727.PDF

217. Vulnerability and adaptive capacity of smallholder farmers in Ho Ho Sub-watershed, Ha Tinh Province, Vietnam http://dx.doi.org/10.5716/WP15728.PDF

218. Local Knowledge on the role of trees to enhance livelihoods and ecosystem services in northern central Vietnam http://dx.doi.org/10.5716/WP15729.PDF

219. Land-use/cover change in Ho Ho Sub-watershed, Ha Tinh Province, Vietnam. http://dx.doi.org/10.5716/WP15730.PDF

2016

220. Agroforestry and Forestry in Sulawesi series: Evaluation of the Agroforestry Farmer Field Schools on agroforestry management in South and Southeast Sulawesi, Indonesia. http://dx.doi.org/10.5716/WP16002.PDF

221. Farmer-to-farmer extension of livestock feed technologies in Rwanda: A survey of volunteer farmer trainers and organizations. http://dx.doi.org/10.5716/WP16005.PDF

222. Projected Climate Change Impact on Hydrology, Bioclimatic Conditions, and Terrestrial Ecosystems in the Asian Highlands http://dx.doi.org/10.5716/WP16006.PDF

223. Adoption of Agroforestry and its impact on household food security among farmers in Malawi http://dx.doi.org/10.5716/WP16013.PDF

224. Agroforestry and Forestry in Sulawesi series: Information channels for disseminating innovative agroforestry practices to villages in Southern Sulawesi, Indonesia http://dx.doi.org/10.5716/WP16034.PDF

225. Agroforestry and Forestry in Sulawesi series: Unravelling rural migration networks.Landtenure arrangements among Bugis migrant communities in Southeast Sulawesi. http://dx.doi.org/10.5716/WP16035.PDF

226. Agroforestry and Forestry in Sulawesi series: Women's participation in agroforestry: more benefit or burden? A gendered analysis of Gorontalo Province. http://dx.doi.org/10.5716/WP16036.PDF

227. Kajian Kelayakan dan Pengembangan Desain Teknis Rehabilitasi Pesisir di Sulawesi Tengah. http://dx.doi.org/10.5716/WP16037.PDF

228. Selection of son tra clones in North West Vietnam. http://dx.doi.org/10.5716/WP16038.PDF 
229. Growth and fruit yield of seedlings, cuttings and grafts from selected son tra trees in Northwest Vietnam http://dx.doi.org/10.5716/WP16046.PDF

230. Gender-Focused Analysis of Poverty and Vulnerability in Yunnan, China http://dx.doi.org/10.5716/WP16071.PDF

231. Seri Agroforestri dan Kehutanan di Sulawesi: Kebutuhan Penyuluhan Agroforestri untuk Rehabilitasi Lahan di Sumba Timur, Nusa Tenggara Timur, Indonesia. http://dx.doi.org/10.5716/WP16077.PDF

232. Agroforestry and Forestry in Sulawesi series: Agroforestry extension needs for land rehabilitation in East Sumba, East Nusa Tenggara, Indonesia. http://dx.doi.org/10.5716/WP16078.PDF

233. Central hypotheses for the third agroforestry paradigm within a common definition. http://dx.doi.org/10.5716/WP16079.PDF

234. Assessing smallholder farmers' interest in shade coffee trees: The Farming Systems of Smallholder Coffee Producers in the Gisenyi Area, Rwanda: a participatory diagnostic study. http://dx.doi.org/10.5716/WP16104.PDF

235. Review of agricultural market information systems in |sub-Saharan Africa. http://dx.doi.org/10.5716/WP16110.PDF

236. Vision and road map for establishment of a protected area in Lag Badana, Lower Jubba, Somalia. http://dx.doi.org/10.5716/WP16127.PDF

237. Replicable tools and frameworks for Bio-Carbon Development in West Africa. http://dx.doi.org/10.5716/WP16138.PDF

238. Existing Conditions, Challenges and Needs in the Implementation of Forestry and Agroforestry Extension in Indonesia. http://dx.doi.org/10.5716/WP16141.PDF

239. Situasi Terkini, Tantangan dan Kebutuhan Pelaksanaan Penyuluhan Kehutanan dan Agroforestri di Indonesia. http://dx.doi.org/10.5716/WP16142.PDF

240. The national agroforestry policy of India: experiential learning in development and delivery phases. http://dx.doi.org/10.5716/WP16143.PDF

241. Agroforestry and Forestry in Sulawesi series: Livelihood strategies and land-use system dynamics in Gorontalo. http://dx.doi.org/10.5716/WP16157.PDF

242. Seri Agroforestri dan Kehutanan di Sulawesi: Strategi mata pencaharian dan dinamika sistem penggunaan lahan di Gorontalo. http://dx.doi.org/10.5716/WP16158.PDF

243. Ruang, Gender dan Kualitas Hidup Manusia: Sebuah studi Gender pada komunitas perantau dan pengelola kebun di Jawa Barat. http://dx.doi.org/10.5716/WP16159.PDF

244. Gendered Knowledge and perception in managing grassland areas in East Sumba, Indonesia. http://dx.doi.org/10.5716/WP16160.PDF

245. Pengetahuan dan persepsi masyarakat pengelola padang aavana, Sebuah Kajian Gender di Sumba Timur. http://dx.doi.org/10.5716/WP16161.PDF

246. Dinamika Pengambilan Keputusan pada komunitas perantau dan pengelola kebun di Jawa Barat. http://dx.doi.org/10.5716/WP16162.PDF

247. Gaharu (eaglewood) domestication: Biotechnology, markets and agroforestry options. http://dx.doi.org/10.5716/WP16163.PDF

248. Marine habitats of the Lamu-Kiunga coast: an assessment of biodiversity value, threats and opportunities. http://dx.doi.org/10.5716/WP16167.PDF

249. Assessment of the biodiversity in terrestrial landscapes of the Witu protected area and surroundings, Lamu County Kenya. http://dx.doi.org/10.5716/WP16172.PDF

250. An ecosystem services perspective on benefits that people derive from biodiversity of Coastal forests in Lamu County, Kenya http://dx.doi.org/10.5716/WP16173.PDF 
251. Assessment of the biodiversity in terrestrial and marine landscapes of the proposed Laga Badana National Park and surrounding areas, Jubaland, Somalia.

http://dx.doi.org/10.5716/WP16174.PDF

2017

252. Preferensi Petani terhadap Topik Penyuluhan dan Penyebaran Informasi Agroforestri di Indonesia. http://dx.doi.org/10.5716/WP16181.PDF 

The World Agroforestry Centre is an autonomous, non-profit research organization whose vision is a rural transformation in the developing world as smallholder households increase their use of trees in agricultural landscapes to improve food security, nutrition, income, health, shelter, social cohesion, energy resources and environmental sustainability. The Centre generates science-based knowledge about the diverse roles that trees play in agricultural landscapes, and uses its research to advance policies and practices, and their implementation that benefit the poor and the environment. It aims to ensure that all this is achieved by enhancing the quality of its science work, increasing operational efficiency, building and maintaining strong partnerships, accelerating the use and impact of its research, and promoting greater cohesion, interdependence and alignment within the organization.

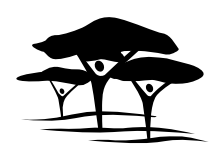

United Nations Avenue, Gigiri • PO Box 30677 • Nairobi, $00100 \cdot$ Kenya Telephone: +254207224000 or via USA +16508336645 Fax: +254207224001 or via USA +16508336646 Email: worldagroforestry@cgiar.org•www.worldagroforestry.org

Southeast Asia Regional Program • Sindang Barang • Bogor 16680 PO Box $161 \cdot$ Bogor $16001 \cdot$ Indonesia

Telephone: +62 $2518625415 \cdot$ Fax: +62 2518625416 